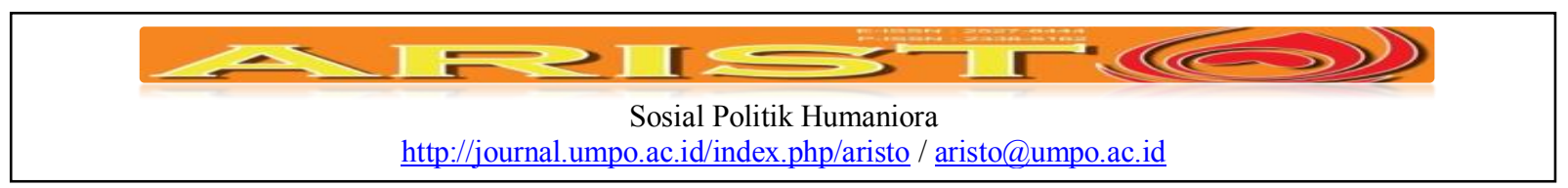

\title{
Pembingkaian Berita Pada Media Lokal (Analisis Framing Pemberitaan Calon Bupati Malang Pada Harian Radar Malang Tanggal 1-7 Oktober 2015)
}

\author{
Rahadi \\ Program Studi Ilmu Komunikasi, FISIP, \\ Universitas Muhammadiyah Malang. \\ Rahadi.umm@gmail.com
}

\begin{abstract}
This research were focused on the news in the newspapers Radar Malang, about construction news regent and deputy regent candidate Malang October 1-7, 2015. There were three candidates for the election of the Regent and Vice Regent 2015-202 period, namely: the candidate regent Malang; (1) Nurcholis Muhammad Mufid of independent elements, (2) Renda Krishna and M Sanusi of coalition Madep Manteb Mantep (PKB, NasDem, Golkar, Gerindra, Democrat), (3) Dewanti Rumpoko and Masrifah Hadi from PDIP. Researchers used the theory of hierarchy levels to understand, how the framing of information on the three pairs of candidates. In this study, researchers used the analytical model and the framing of Zhongdang Pan Geraald Konsicki. The model uses four structural framing is Syntactically, Scripts, Thematic and Rhetoric.Based on study results, the news displayed by Radar Malang less balanced. This is evident from the Renda Krishna as the incumbent is given the space and the number of reports that more than any other potential mates. And their special news column titled Coming 5 Years Madep Manteb. Plus on the first page is kept up Radar Malang given space to direct the reader linked to column 5 Years Ahead Madep Manteb along with the headline raised. Associated with the theory of hierarchy levels, from internal factors, namely the level of the organizational level, and the level of media routines is clear that extremely pro Radar Malang Renda Krishna. This is evidenced by the news that tends to be positive.
\end{abstract}

Keywords: Framing Analysis, Radar Malang, Ideology Media

\section{Abstrak}

Penelitian ini memokuskan pada berita dikoran Radar Malang, tentang konstruksi pemberitaan kandidat Bupati dan wakil bupati Malang tanggal 1-7 Oktober 2015. Ada tiga kandidat untuk pemilihan Bupati dan Wakil Bupati Malang periode 2015-202, yaitu: pasangan calon bupati Malang; (1) Nurcholis Muhammad Mufid dari unsur independen, (2) Rendra Kresna dan M Sanusi dari koalisi Madep Manteb Mantep (PKB, NasDem, Golkar, Gerindra, Demokrat), (3) Dewanti Rumpoko dan Masrifah Hadi dari PDIP. Peneliti menggunakan teori hirarki level untuk memahami, bagaimana pembingkaian pemberitaan terhadap ketiga pasangan kandidat tersebut. Dalam penelitian ini, peneliti menggunakan Model analisis framing dari Zhongdang Pan dan Geraald Konsicki. Model framing ini menggunakan empat struktur yaitu Sintaktis, Skrip, Tematik, dan Retoris. Berdasarkan hasil Penelitian, pemberitaan yang ditampilkan oleh Radar Malang kurang berimbang. Hal ini terlihat dari Rendra Kresna selaku incumbent diberikan space dan jumlah pemberitaan yang lebih banyak dibandingkan dengan calon pasangan yang lain. Dan adanya kolom pemberitaan khusus yang diberi judul Jelang 5 Tahun Madep Manteb. Ditambah lagi pada halaman pertama Radar Malang selalui diberikan space untuk mengarahkan 


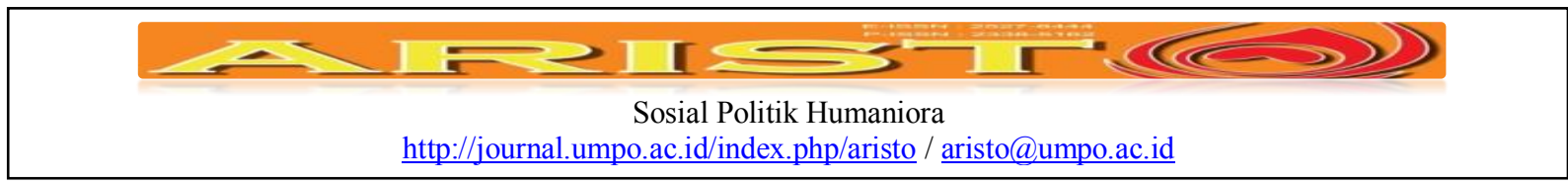

pembaca terkait dengan kolom Jelang 5 Tahun Madep Manteb beserta dengan judul berita yang diangkat. Dikaitkan dengan teori hirarki level, dari faktor internal level yaitu level organisasi, dan level rutinitas media jelas bahwa Radar Malang sangat berpihak pada Rendra Kresna. Hal ini dibuktikan dengan pemberitaan yang cenderung bersifat positif.

Katakunci: Analisis framing, Radar Malang, Ideologi Media

\begin{tabular}{|ll|}
\hline Submite & $:$ 12 Nov 2016 \\
Review & $:$ 22 Nov 2016 \\
Accepted & $:$ 01 Jan 2017 \\
Surel Corespondensi & $:$ jovani.audra@gmail.com_adamhilman@umpo.ac.id \\
\hline
\end{tabular}

\section{Pendahuluan}

Pascareformasi, media massa memegang peranan penting dalam kehidupan politik di Indonesia. Kekuasaan media dalam menyajikan atau melaporkan peristiwa-peristiwa politik dalam bentuk berita sering memberi dampak signifikan bagi perkem-bangan politik di tanah air. Media massa bukan saja sebagai sumber informasi politik, tetapi menjadi faktor pemicu (trigger) terjadinya perubahan politik. Hal ini meng-ingat kemampuan dan kekuasaan media massa dalam mempengaruhi masyarakat atau khalayak lewat pembentukan opini dan wacana yang diwartakan. Runtuhnya rezim otoritarian Orde Baru lewat gerakan reformasi tahun 1998, diikuti dengan kebebasan pers, telah mengubah tatanan dan kondisi politik Indonesia menuju ke arah demokratisasi. Reformasi telah mengubah dunia pers di Indonesia, dengan tidak lagi terkungkung dalam keseragaman isi dan kemasan. Media pada era dan pascareformasi dapat bebas mengembangkan model pemberitaan sesuai keinginan. Kata "bebas", pada perkembangannya bisa bermakna lain, sebab sulit untuk memper-cayai bahwa media adalah entitas yang benar-benar otonom dan mandiri. Meskipun rezim sudah berganti dan iklim politik telah sedemikian terbuka, tetap diperlukan kecurigaan terhadap faktor-faktor eksternal dan internal yang berpotensi mempengaruhi perilaku media dalam mengkonstruksi dan memaknai realitas (Sudibyo, 2006: 1).

Bukan menjadi sesuatu rahasia jika media yang seharusnya menjadi lembaga keempat (fourth estate) yang mengawal proses demokratisasi (di ranah lokal), justru media lokal banyak yang berubah fungsi menjadi kepanjangan pemimpin daerah, sehingga media lokal dalam tinjauan komunikasi politik lebih berperan sebagai agen politik daripada saluran komunikasi politik.Dalam membuat liputan berita politik yang memiliki dimensi pembentukan opini publik, media massa umumnya melakukan tiga kegiatan sekaligus yang dipakai untuk mengkonstruksi 


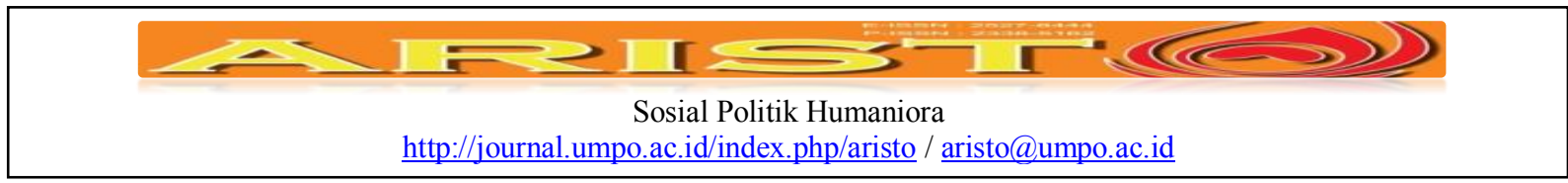

realitas. Pertama, menggunakan simbol-simbol politik (langue of politic), kedua, melaksanakan strategi pengemasan pesan (framing strategies), ketiga, melakukan fungsi agenda setting media (agenda setting function). Dari konstruksi dalam pembuatan berita sangat dimungkinkan media juga melakukan manipulasi-manipulasi untuk mencapai apa yang diinginkannya (Rivers, 2015:39). Dengan demikian boleh jadi satu peristiwa politik bisa menimbulkan opini publik yang berbeda-beda tergantung dari cara masing-masing media mengkonstruksi berita politik (Hamad, 2004: 2-3).

Melihat realitas diatas, penelitian ini memfokuskan pada pemberitaan yang terdapat pada harian pagi Radar Malang dalam memberitakan pasangan Bupati Malang tanggal 1-7 Oktober 2015. Pilkada kabupaten Malang untuk memlilh kepala daerahnya saat ini diikuti oleh tiga pasangan yaitu pasangan calon bupati Malang yakni Nurcholis dan Muhammad Mufid dari jalur independen (Pasangan No urut 3), Rendra Kresna dan M Sanusi (Pasangan No urut 1), dari koalisi Madep Manteb (PKB, NasDem, Golkar, Gerindra, Demokrat), serta Duo Srikandi Dewanti Rumpoko dan Masrifah Hadi dari PDIP (Pasangan No urut 2). Lebih lanjut peneliti ingin mengetahui bagaimana pembingkaian pemberitaan terhadap ketiga pasangan calon diatas pada media cetak yang menjadi salah satu media terbesar di kota Malang. Hal ini disebabkan adanya kecurigaan peneliti bahwa netralitas media lokal dalam pemilihan kepala daerah misalnya, lebih mengutamakan kepentingan ekonomi dan politis daripada fungsi informsi dan fungsi pendidikan untuk masyarakat sehingga mereduksi peran media. Berdasarkan latar belakang masalah yang telah peneliti ajukan diatas maka dapat diambil rumusan masalah yaitu Bagaimana Pembingkaian Berita oleh media lokal Radar Malang pada pemberitaan calon Bupati Malang Pada Harian Radar Malang tanggal 1-7 Oktober 2015. Penelitian ini mempunyai tujuan yaitu mengetahui Pembingkaian Berita oleh media lokal Radar Malang pada pemberitaan calon Bupati Malang Pada Harian Radar Malang tanggal 1-7 Oktober 2015.

\section{Metode}

Dalam penelitian ini, peneliti menggunakan pendekatan kualititif. Alasan menggunakan pendekatan kualitatif adalah; dengan pendekatan kualitatif peneliti dapat menjelaskan realitas dengan menggunakan penjelasan secara deskriptif dalam bentuk kalimat. Selanjutnya metode analisis yang digunakan adalah analisis framing dari Model Zhongdang Pan dan Gerarld 


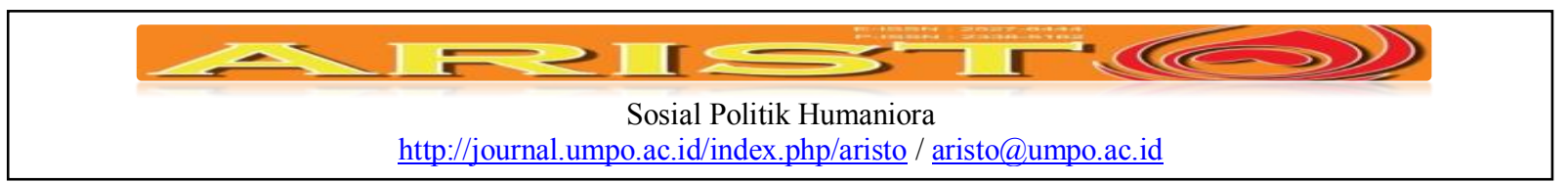

M.Kosicki. Pada model analisis framing ini, melihat wacana publik mengenai isu atau kebijakan dikontruksikan dan dinegosiasikan melalui media (Eriyanto, 2011: 281-290).

Ruang lingkup penelitian ini adalah pemberitaan pada Radar Malang pada bulan oktober 2015. Data yang digunakan sebagai bahan penelitian adalah berita yang terkait dengan pemberitaan pasangan calon Bupati Malang. Sehingga tidak semua berita yang dimuat di Radar Malang menjadi bahan penelitian. Adapun berita yang sudah terseleksi sesuai dengan kebutuhan penelitian ini adalah sebagai berikut:

1. Jelang 5 Tahun Madep Manteb: 5 Tahun, Bisa Entas 104 Desa Tertinggal

2. Bupati Janjikan Pertanian Modern

3. Geng Wahyudi Dukung Rendra

4. Jelang 5 Tahun Madep Manteb: Lenggoksono Jadi Destinasi Wisata Internasional

5. Jelang 5 Tahun Madep Manteb: Soal kesehatan, indeks kepuasan masyarakat di atas 80 persen

6. Jelang 5 Tahun Madep Manteb: perkuat 13 Pokdarwis untuk tingkatkan pariwisata

7. Jelang 5 Tahun Madep Manteb: Di Karangploso, Rendra Kresna Kampanye-kan Keselamatan Kerja

8. Dewanti Jala Dukungan Pemilih Perempuan

9. Rendra jualan objek wisata

Dari pemberitaan yang dimuat pada bulan tanggal 1-7 oktober 2015, peneliti menemukan ada 9 pemberitaan yang terkait dengan pemberitaan Calon Bupati Malang tahun 2015. Namun dari rentang waktu antara tanggal 1-7 oktober 2015 tidak setiap hari ada pemberitaan yang terkait dengan pemberitaan Calon Bupati Malang. Teknik pengumpulan data dilakukan dengan cara mendokumentasikan pemberi-taan terkait pencalonan Bupati Malang tahun 2015 dengan cara repro foto. Cara ini diambil karena mengingat ukuran koran yang besar sehingga tidak memungkin untuk dilakukan dengan cara scaning. Analisis data penelitian yang digunakan adalah analisis framing Zhongdang Pan dan Konsicki. Analisis ini merupakan salah satu model analisis framing yang popular dan banyak digunakan dalam analisis teks media. Analisis framing secara sederhana dapat digambarkan sebagai analisis untuk mengetahui bagaimana realitas (persitiwa, aktor, kelompok, atau apa saja) dibingkai oleh media. Pembingkaian itu tentu saja melalui proses konstruksi. Disini realitas sosial dimaknai dan dikonstruksi dengan makna tertentu. Hasilnya, pemberitaan media pada sisi tertentu atau wawancara dengan orang tertentu. Semua elemen tersebut tidak hanya bagian dari teknik jurnalistik, tetapi menandakan bagaimana peristiwa dimaknai dan ditampilkan (Eriyanto, 2011:3) 


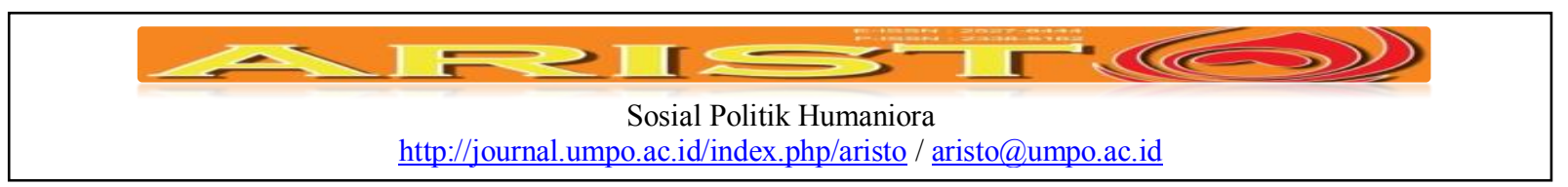

Menurut Pan dan Kosicki untuk menonjolkan pemaknaan atau penafsiran atas realitas harus memakai sebuah strategi kata, kalimat, lead, hubungan antar kalimat, foto, grafik, dan perangkat lain untuk membantu dirinya mengungkapkan pemaknaan mereka sehingga dapat dipahami. Adapun jika dituangkan dalam bentuk struktur maka sebagai berikut

1. Struktur sintaksis: bagaimana fakta disusun oleh wartawan sehingga sesuai dengan skema yang dibutuhkan

2. Struktur skrip: bagaimana menceritakan informasi dalam kaedah $5 \mathrm{~W} 1 \mathrm{H}$

3. Struktur tematik: bagaimana fakta ditulis oleh wartawan terkait dengan pe-nempatan kata dan koherensi kata dalam kalimat serta penempatan sumber kedalam teks berita secara keseluruhan

4. Struktur retoris: terkait dengan pilihan gaya atau kata yang dipilih oleh wartawan untuk menekankan arti yang ingin ditonjolkan oleh wartawan.

Bila dibuat dalam sebuah tabel maka struktur analisis akan seperti dibawah ini

Tabel.1

Struktur Model Analisis Zhongdang Pan dan Kosicki

\begin{tabular}{|l|l|l|}
\hline \multicolumn{1}{|c|}{ STRUKTUR } & PERANGKAT FRAMING & \multicolumn{1}{c|}{ UNIT YANG DIAMATI } \\
\hline $\begin{array}{l}\text { SINTAKSIS } \\
\text { (cara wartawan menyusun } \\
\text { fakta) }\end{array}$ & Skema berita & $\begin{array}{l}\text { Headline, lead, latar informasi, kutipan, } \\
\text { sumber, pernyataan, penutup }\end{array}$ \\
\hline $\begin{array}{l}\text { SKRIP } \\
\text { (wartawan menyampaikan } \\
\text { fakta) }\end{array}$ & Kelengkapan berita & $\begin{array}{l}\text { What, Who, When, Where, Why, How } \\
(5 \mathrm{~W}+1 \mathrm{H})\end{array}$ \\
\hline $\begin{array}{l}\text { TEMATIK } \\
\text { (cara wartawan menuliskan } \\
\text { fakta) }\end{array}$ & $\begin{array}{l}\text { Detail, konherensi, bentuk } \\
\text { kalimat, kata ganti }\end{array}$ & $\begin{array}{l}\text { Paragraf, proposisi, kalimat, hubungan } \\
\text { antar kalimat }\end{array}$ \\
\hline $\begin{array}{l}\text { RETORIS } \\
\text { (cara wartawan menekankan } \\
\text { fakta) }\end{array}$ & Leksion, Grafis, metafora & Kata, idiom, gambar/ foto, grafik \\
\hline
\end{tabular}

(sumber: Eriyanto, 2011:295)

\section{Komunikasi Politik Dalam Media Massa}

Dalam melakukan kegiatan komunikasi politik tentu tidak terlepas dari saluran saluran atau media yang akan digunakan. Hal ini terkait dengan efekfititas kegiatan komunikasi yang dilakukan. Jadi seorang komunikator politik lantas mengidentifikasikan klasifikasi basis massa yang akan mendapatkan kegiatan politiknya dapat dijangkau dengan media apa. Apakah menggunakan caraface to face ataukah menggunakan media massa.Menurut Antonio Gramsci 


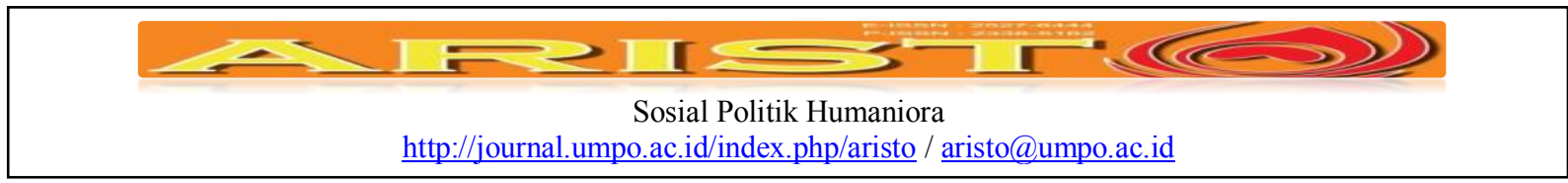

seperti yang dikutip oleh Alex Sobur media merupakan arena pergulatan antar ideologi yang saling berkompetisi (the battle ground for competing ideologies). Gramsci melihat media sebagai ruang dimana berbagai ideologi dipresentasikan. Ini berarti, di satu sisi media bisa menjadi sarana penyebaran sebuah ideology. Baik ideologi penguasa maupun ideologi yang berseberangan dengan penguasa. Dalam kegiatan komunikasi politik, fungsi media massa sebagai sumber informasi politik, fungsi partisipasi, fungsi sosialisasi dan pendidikan politik, fungsi mengembangkan budaya politik, fungsi integritas bangsa. Selain itu media juga berperan sebagai fungsi sosial, hiburan dan kontrol.

Romli (2007:1-2) mengatakan media massa dalam melakukan fungsi sebagai sumber informasi selalu menyajikan, menayangkan peristiwa peristiwa politik yang terjadi di berbagai penjuru dunia, termasuk kegiatan aktor-aktor politik dengan sikap dan perilaku politik yang melekat pada para aktor tersebut. Sebagai fungsi sumber informasi lebih menitik beratkan kepada unsur-unsur berita (news) yang berefek pada kepentingan politik. Beberapa unsur-unsur yang harus dipenuhi dalam pemberitaan politik, yaitu: publisitas, aktualitas dan popularitas.

Fungsi kedua, yaitu fungsi partisipasi. Hal ini mengandung makna bahwa sajian atau tayangan pesan-pesan komunikasi baik pada media elektronik maupun media cetak harus mampu menggugah masyarakat (komunikan) untuk berperan aktif dalam mendukung dan melaksanakan berbagai kebijaksanaan pemerintah sebagai konsekuensi bahwa pemerintah adalah produk pilihan mereka.Fungsi ketiga, sosialisasi dan pendidikan politik. Fungsi ini untuk meningkatkan kesadaran masyarakat didalam menerima segala bentuk informasi. Memang fungsi sosialisasi dan pendidikan politik merupakan salah satu bentuk tanggung jawab dari adanya partaipolitik.Namun tidak dapat dipungkiri bahwa media massa juga mempunyai tanggung jawab atas sosialisasi dan pendidikan politik yang harus bebas dari kepentingan partai politik walaupun saat ini masih sulit untuk dilakukanmengingat para petinggi partai politik di Indonesia juga merupakan pemilik media. Fungsi keempat, yaitu membangun politic culture (budaya politik). Budaya politik membentuk pola perilaku yang memberi warna dominan terhadap karakter masyarakat. Apakah mempunyai karakter tradisional atau rasional. Fungsi kelima, yaitu fungsi integritas bangsa. Fungsi ini merupakan syarat mutlak bagi kehidupan negara di dalam mencapai tujuannya. Karena itu media massa harus mampu mengembangkan pemikiran-pemikiran yang menyatukan bangsa. 


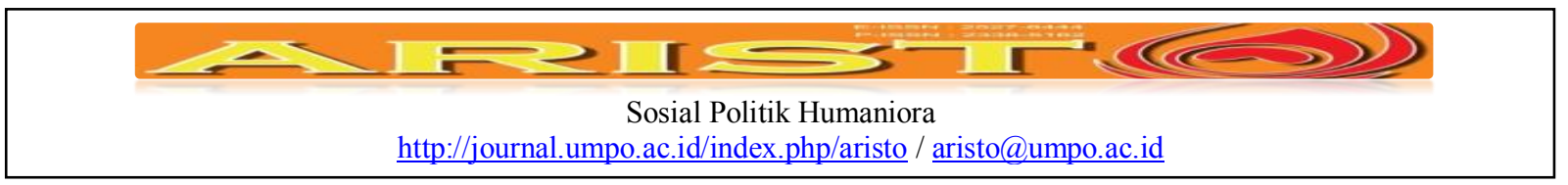

\section{Konstruksi Berita Kampanye di Media Cetak}

Pada prinsipnya, konstruksi realitas kampaye politik di media cetak (juga bisa pada media yang lain) merupakan usaha untuk membentuk dan mempersepsikan dengan cara menceritakan hal-hal yang berkaitan tentang akan kepentingan politik suatu golongan. Aktivitas media tak terlepas dari penyampaian realitas atau peristiwa yang sudah barang tentu akan dikonstruksikan sedemikian rupa oleh para pengambil kebijakan (ini merupakan faktor internal media). Selain faktor internal juga terdapat factor eksternal yang mempengaruhi konstruksi pemberitaan yaitu faktor eksternal. Faktor eksternal ini adalah realitas pasar dan kenyataan politik. Di era politik modern saat ini, media massa tidak hanya menjadi bagian menyatu dengan dari politik (mengingat para pemilik media di Indonesia notabene adalah para pemilik media juga) tetapi memiliki fungsi yang sangat vital dalam percaturan politik. Posisi utama dalam dunia politik dalam meraih kekuasaan membuat partai politik (bisa juga bakal calon) menggunakan media massa sebagai saluran politiknya. Hal ini semakin menguatkan bahwa media massa mempunyai peran yang sangat penting dalam proses politik.

Menurut Laswell sebagaimana dikutip Pawito dalam buku komunikasi politik, media massa, dan kampanye pemilihan (2009:87-88), media massa mempunyai tiga fungsi pokok dalam dunia politik yaitu:

1. Fungsi pengawasan: merujuk pada aktifitas mencermati dan melaporkan peristiwa penting kepada publik

2. Fungsi Penghubung: sarana berdiskusi, bertukar pendapat, dan aspirasi bagi seluruh kelompok masyarakat.

3. Fungsi Transmisi warisan social: proses sosialisasi nilai, norma, dan kesepakan yang berkembang di masyarakat agar tercapai aturan social.

Pendapat Laswell diatas memang merupakan sebuah idealisme dari media massa. Namun pada kenyataan, saat ini media massa tidak lagi sebuah lembaga yang murni dalam perjuangannya. Media menjadikan dirinya sebuah kelompok dominan yang menyebarkan pengaruhnya dengan meminggirkan kelompok yang lain.

\section{Media Sebagai Perayu Ulung}

Saat ini hampir setiap hari kita tak lepas dari smartphone. Mencari berita, membagikan berita, berkomunikasi dengan teman, berjualan secara online dan masih banyak lagi dapat kita 


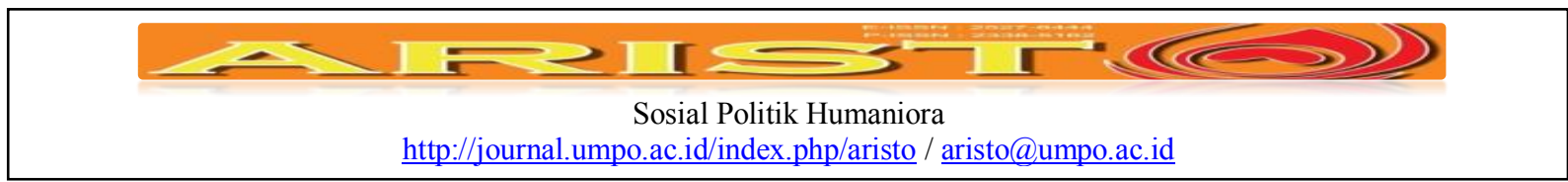

lakukan dengan sangat mudah. Semua sudah berada ditangan kita. Namun disisi lain terkait dengan informasi yang bertebaran dimedia internet tak sedikit informasi atau berita yang tidk dapat dipertanggung jawabkan kebenarannya, bahkan yang paling fatal adalah tak jarang pula informasi atau berita tersebut diberitakan oleh portal-portal berita mainstream. Menurut Ardian husaini yang dikutip oleh kun wasis dalam bukunya media massa dan kontruksi realitas (2012: 137) dalam kode etik jurnalistik PWI ada aturan yang melarang untuk mencampuradukkan antara fakta dan opini. Fakta harus disajikan sebagai fakta, dan begitu juga dengan opini harus disajikan sebagai opini. Sehingga keberimbangan atas berita yang disampaikan tetap terjaga. Realitas yang dapat kita saksikan saat ini adalah begitu banyaknya penggiringan opini publik yang menjadi konten berita pada media massa untuk kepentingan kelompok tertentu. Apabila opini yang dibuat oleh media massa ini sudah terbentuk di masyarakat, maka akan muncul pemaknaan atas sesuatu yang bersifat general yang cenderung untuk menuduh, mengunggulkan kelompok tertentu. Untuk mengurangi dampak dari munculnya konten-konten yang tidak bisa dipertanggung jawabkan isinya tersebut, maka ada langkah-langkah yang harus dilakukan. Menurut Effendi Gazali langkah-langkah tersebut adalah: membaca banyak sumber dari buku yang membahas tentang media selanjutnya membangun pengetahuan tentang literasi media, dan yang terakhir pemahaman bahwa dalam memproduksi berita pasti ada benturan antara struktur (sumber daya) dan agensi (tindakan, entah itu dari jurnalis/ editor/redaktur)

\section{Level Pengaruh Isi Media}

Melihat kenyataan atau realitas tentu menarik untuk dilihat lebih mendalam lagi hal-hal yang mempengaruhi atau bisa dikatakan mengintervensi media massa dalam membe-ritakan sebuah realitas. Menurut Pamela J. Shoemaker dan Stephen D. Reese, beberapa faktor yang mempengaruhi pengambilan keputusn dalam pemebritaan realitas di media massa adalah sebagai berikut:

1. Level individu: berhubungan dengan latar belakang pengelola media. Bisa dilihat dari aspek latar belakang pendidikan, jenis kelamin, agama, ideology.

2. Level rutinitas media: mekanisme dan proses penentuan berita yang akan diproduksi sampai pada tahap naik cetak

3. Level organisasi: berhubungan dengan struktur organisasi yang secara hirarki pasti akan mempengaruhi pemberitaan

4. Level ekstramedia: berhubungan dengan lingkungan diluar media misalnya sumber berita (narasumber), sumber penghasilan media, kebijakan pemerintah. 


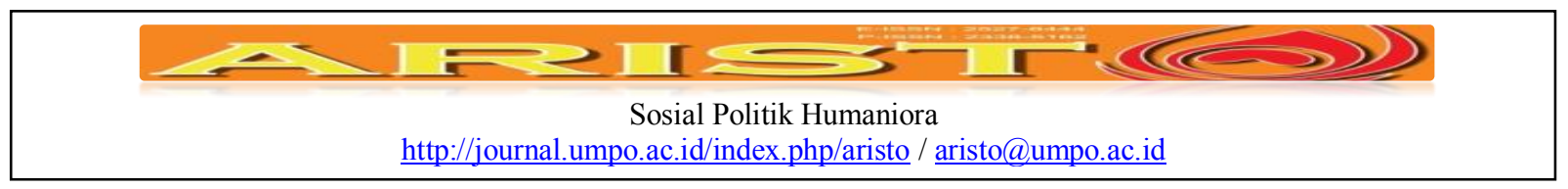

5. Level ideologi: kerangka berpikir atau referensi yang dipakai oleh individu untuk melihat realitas. (Sudibyo, 2001:7)

Untuk mengungkapkan pembingkaian pemberitaan calon Bupati Malang pada surat kabar

Radar Malang peneliti menggunakan pendekatan kualitatif dengan tipe inte-pretatif serta analisis framing untuk menganalisis pembingkaian yang dibuat oleh Radar Malang. Analisis framing menekankan pada realitas yang dikonstruksi oleh media. Lebih lanjut dengan analisis framing dapat diketahui berita tersebut ada bagian yang disem-bunyikan bahkan dihilangkan. Dengan framing, wartawan mengemas peristiwa yang beragam menjadi peris-tiwa yang mudah dipahami, dengan sudut pandang tertentu yang menarik serta meng-giring intepretasi pembaca sesuai dengan perspektif yang sudah direncanakan. Sehingga bisa dikatakan bahwa framing adalah pendekatan untuk mengetahui bagaimana per-spektif yang digunakan oleh pemilik media/wartawan dalam menyeleksi isu serta menulis berita.

\section{Hasil dan Pembahasan}

\section{Berita tanggal : 2 Oktober 2015}

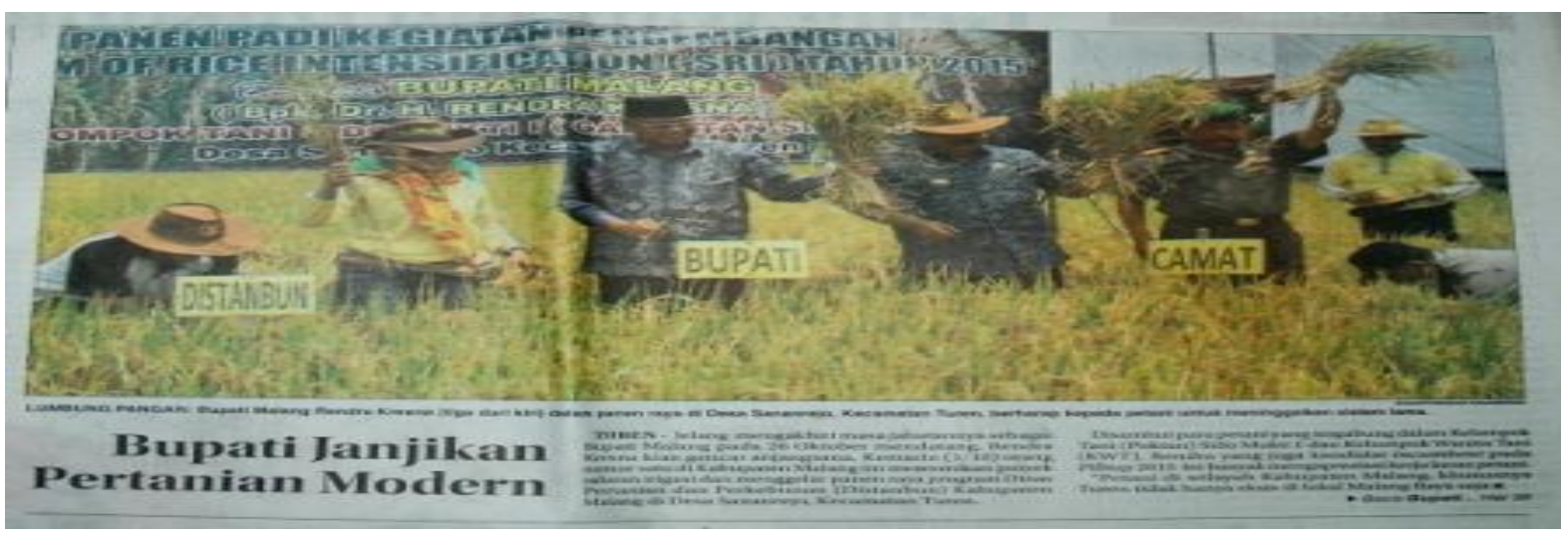

\section{Judul: Bupati Janjikan Pertanian Modern}

\section{Isi Berita:}

Bu pati Rendra juga berjanji akan mengusahakan bantuan peralatan pertanian yang lebih modern, di luar bantuan tiga buah hand tractor. "Alat yang lebih baru nanti akan lebih hemat sekitar lima persen pungkasnya. Sementara itu, Tommie Herawanto kepala Distanbun Kabupaten Malang menambahkan. kegiatan kemarin juga dilakukan peresmian program hibah pembangunan saluran irigasi dari anggaran APBN melalui program Upsus (upaya khusus) Pemerintah RI. Pembangunan saluran irigasi ini direncanakan 310 meter panjangnya namun terealisasi 426 meter berkat partisipasi warga. "Diharapkan nanti akan lebih maksimal mengaliri 20 hektar lahan pertanian di Dusun Betek Desa Sananrejo," jelas Tommie.(zal/nay) 


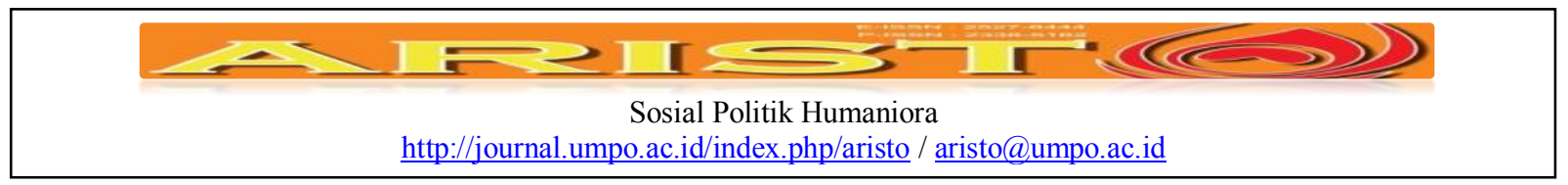

Tabel 2

Analisis Framing Pan Dan Kosicki Berita Diatas

\begin{tabular}{|c|c|c|}
\hline Perangkat & Unit pengamatan & Hasil pengamatan \\
\hline \multirow{6}{*}{$\begin{array}{l}\text { STRUKTUR } \\
\text { SINTAKSIS }\end{array}$} & Judul & Bupati Janjikan Petanian Modern \\
\hline & Lead & $\begin{array}{l}\text { Turen: Jelang mengakhiri masa jabatannya sebagai Bupati Malang } \\
\text { pada oktober } 2016 \text { mendatang, Rendra Kresna kian gencar } \\
\text { anjangsana. Kemarin (1/10) orang nomer satu di kabupaten Malang } \\
\text { ini meresmikan proyek saluran irigasi dan menggelar panen raya } \\
\text { program dinas pertanian dan perkebunan (distanbun)kabupaten } \\
\text { Malang di Desa Sananrejo, Kecamatan Turen. }\end{array}$ \\
\hline & Latar informasi & $\begin{array}{l}\text { "Petani di wilayah Kabupaten Malang khususnya Turen tidak hanya } \\
\text { eksis di lokal Malang Raya saja. Peranannya sekarang juga } \\
\text { menasional terutama dalam program pemerintah soal ketahanan } \\
\text { pangan nasional," kata Rendra usai melakukan prosesi panen raya } \\
\text { bersama Muspika Turen. Para petani, lanjut Rendra, ibaratnya } \\
\text { pejuang masa kini. Oleh karena itu usaha dan jerih payahnya harus } \\
\text { diapresiasi. Karena itu, teknologi pertanian juga harus diterapkan } \\
\text { dengan penggunaan peralatan yang modern. "jangan pakai system } \\
\text { lama seperti gebyok padi. Itu dapat mengurangi jumlah panen } \\
\text { sekitar } 15 \text { persen, eman (sayang, red) terbuang percuma," } \\
\text { imbuhnya. }\end{array}$ \\
\hline & Kutipan sumber & $\begin{array}{l}\text { Tommie Herawanto, Kepala Distanbun Kabupaten Malang } \\
\text { menambahkan, kegiatan kemarin juga dilakukan peresmian program } \\
\text { hibah pembangunan saluran irigasi dari anggaran APBN melalui } \\
\text { program Upsus (upaya khusus) Pemerintah RI. Pembangunan } \\
\text { saluran irigasi ini direncanakan } 310 \text { meter panjangnya namun } \\
\text { terealisasi } 426 \text { meter berkat partisipasi warga. "Semoga nanti akan } \\
\text { dimaksimalkan untuk mengaliri } 20 \text { hektar lahan di Dusun Betek } \\
\text { Sananrejo" jelas Tommie }\end{array}$ \\
\hline & $\begin{array}{l}\text { Pernyataan/ opini } \\
\text { penulis }\end{array}$ & \\
\hline & Penutup & $\begin{array}{l}\text { "Semoga nanti akan dimaksimalkan untuk mengaliri } 20 \text { hektar } \\
\text { lahan di Dusun Betek Sananrejo" }\end{array}$ \\
\hline \multirow{6}{*}{$\begin{array}{l}\text { STRUKTUR } \\
\text { SKRIP }\end{array}$} & What & $\begin{array}{l}\text { Rendra Kresna meresmikan proyek saluran irigasi dan menggelar } \\
\text { panen raya program dinas pertanian dan perkebunan (distanbun) } \\
\text { kabupaten Malang di Desa Sananrejo, Kecamatan Turen }\end{array}$ \\
\hline & Who & Rendra Kresna \\
\hline & When & $1 / 10 / 2015$ \\
\hline & Where & Desa Sananrejo, Kecamatan Turen \\
\hline & Why & $\begin{array}{l}\text { Petani di wilayah Kabupaten Malang khususnya Turen tidak hanya } \\
\text { eksis di lokal Malang Raya saja. Peranannya sekarang juga } \\
\text { menasional terutama dalam program pemerintah soal ketahanan } \\
\text { pangan nasional," } \\
\text { Oleh karena itu usaha dan jerih payahnya harus diapresiasi. Karena } \\
\text { itu, teknologi pertanian juga harus diterapkan dengan penggunaan } \\
\text { peralatan modern }\end{array}$ \\
\hline & HOW & $\begin{array}{l}\text { Bupati Rendra juga berjanji akan mengusahakan bantuan peralatan } \\
\text { pertanian yang lebih modern, di luar bantuan tiga buah hand tractor. }\end{array}$ \\
\hline $\begin{array}{l}\text { Struktur } \\
\text { Tematik }\end{array}$ & $\begin{array}{l}\text { Paragraph, proposisi, } \\
\text { kalimat, hubungan }\end{array}$ & $\begin{array}{l}\text { Pada pemberitaan ini terdapat empat paragraph, paragaraf awal } \\
\text { dimulai dengan kalimat penguat tentang kinerja yang dilakukan }\end{array}$ \\
\hline
\end{tabular}

Rahadi. Pembingkaian Berita Pada Media Lokal / 03/ Vol.5. No. 1. Tahun 2017 


\begin{tabular}{|l|l|l|}
\hline \multicolumn{1}{|c|}{ http://journal.umpo.ac.id/index.php/aristo / aristo@umpo.ac.id } \\
\hline \hline Struktur Retoris & $\begin{array}{l}\text { Sosial Politik Humaniora } \\
\text { Kata, idiom, kalimat } \\
\text { gambar/foto, grafik }\end{array}$ & $\begin{array}{l}\text { oleh rendra kresna menjelang purna tugas. paragraph kedua dan } \\
\text { ketiga diisi dengan testimony dari rendra kresna dan paragraph } \\
\text { terakhir oleh kepala distanbun kabupaten Malang }\end{array}$ \\
$\begin{array}{l}\text { Pengunaan kata "berjanji akan mengusahakan" sebagai bentuk dari } \\
\text { penjabaran judul. Dalam foto nampak bupati, camat dan kepala } \\
\text { distanbun }\end{array}$ \\
\hline
\end{tabular}

\section{Berita Tanggal 2 Oktober 2015}

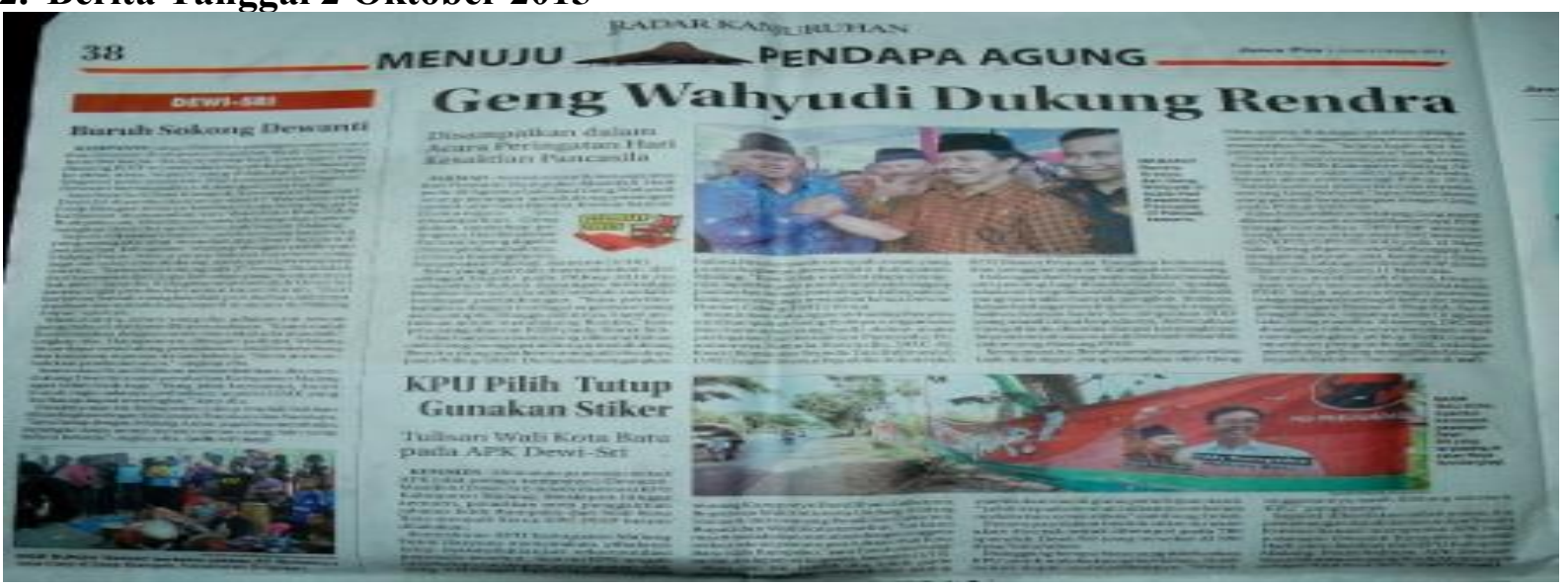

\section{Judul: Geng Wahyudi Dukung Rendra \\ Isi Berita:}

\section{*Disampaikan Dalam Acara Peringatan Hari Kesaktian Pancasila}

PAKISAJI - Setelah menarik dukungannya dari Dewanti Rumpoko-Masrifah Hadi, 10 Agustus lalu, kini Geng Wahyudi terang-terangan mendukung pasangan nomor urut satu Rendra Kresna-Sanusi. Dukungan itu disampaikan Geng dalam sarasehan peringatan Hari Kesaktian Pancasila yang digelar di kompleks rumahnya, di Desa Karangduren, Kecamatan Pakisaji, kemarin (1/10). Pria yang pernah mencalonkan diri sebagai bupati pada pilbup 2010 itu menyebut bahwa dukungan terhadap Rendra-Sanusi diambil setelah melalui berbagai pertimbangan. Saya pertimbangkan dengan organisasi yang saya pimpin, akhinya diputuskan untuk mendukung Rendra," kata pria yang dipecat PDIP, Maret lalu. Tidak banyak alasan yang dikemukakan oleh Geng, mengapa akhirnya mendukung Rendra yang notabene menjadi rivalnya pada pilbup 2010. Dia hanya mengatakan bahwa Rendra masih menjadi sosok yang punya kapasitas memimpin kabupaten Malang. Kami tak lihat siapa orangnya,tapi lebih pada sosok. Yang pantas dan mampu memimpin kabuaten," kata pria yang juga menjabat Ketua Dewan Harian Cabang (DHC) 45 ini. Komitmen dukungan terhadap Rendra ini, disampaikan Geng di depan organisasi dan komunitas yang hadir dalam acara peringatan Hari Kesaktian Pancasila. Diantaranya Pemuda Pancasila, DHC 45, Kosti (Komunitas Sepeda Tua Indonesia), LVRI (Legiun Veteran Republik Indonesia), IPTI (Ikatan Pemuda Tionghoa Indonesia) dan penggiat seni se-Kabupaten Malang. Dukungan dari Geng tentu saja bakal memiliki arti penting bagi Rendra-Sanusi. Apalagi, selama ini Geng dikenal sebagai sosok karismatik yang memiliki banyak pengikut. Bahkan, dalam berbagai kesempatan, Geng mengaku bahwa banyak kader dan simpatisan PDIP yang masih loyal kepadanya. Keberadaan Geng di kubu Rendra-Sanusi kemungkinan bisa memecah suara untuk Dewanti-Masrifah, calon yang diusung PDIP. Sementara itu, Rendra sendiri menyambut baik dukungan yang diberikan oleh Geng. Menurut-nya, dukungan tersebut sekaligus mewakili suara organisasi kepemudaan dan masyarakat luas. "Terima kasih atas kepercayaannya. Mohon doanya," kata Rendra. Ditemui dalam kesempatan yang sama, Ketua DPC PKB Kabupaten Malang Abdulrahman semakin yakin bahwa Rendra-Sanusi akan memenangi pilbup 2015. "Saya kira semua masyara-kat tahu kapasitas seorang 


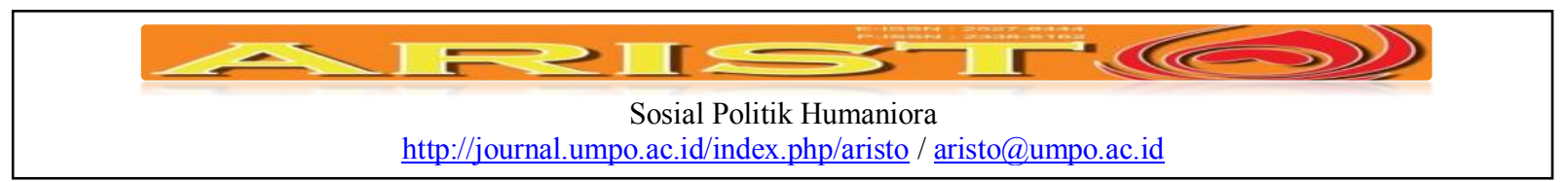

Geng Wahyudi," kata Abdulrahman yang pernah berpasangan dengan Geng, pada pilbup 2010 lalu. Kilas balik sedikit ke belakang, Geng seperti diketahui pernah menjadi kader loyal PDIP. Hingga kemudian, DPP PDIP memecat Geng, lewat surat keputusan (SK) bernomor 425/KPTS/DPP/III/2015 pada 12 Maret lalu. Geng dipecat setelah dianggap bertanggung jawab atas keributan dalam konferensi cabang (konfercab) PDIP di Hotel Utami Sidoarjo, 11 Maret lalu. Namun, meski sudah dipecat, Geng ternyata masih menunjukkan loyalitas kepada PDIP. Salah satunya dengan menerima tanggungjawab sebagai ketua tim relawan pemenangan Dewanti-Masrifah. Tapi di tengah jalan, tepatnya pada 10 Agustus, Geng mundur. Alasannya, DPC PDIP dianggap tidak punya komitmen untuk memenangkan pilbup. Ketika mengumumkan pengunduran diri, sekaligus membuka peluang mengalihkan dukungan kepada Rendra-Sanusi. (sah/muf)

\section{Tabel 3}

\section{Analisis Framing Pan Dan Kosicki Berita Diatas}

\begin{tabular}{|c|c|c|}
\hline Perangkat & Unit pengamatan & Hasil pengamatan \\
\hline \multirow{6}{*}{$\begin{array}{l}\text { STRUKTUR } \\
\text { SINTAKSIS }\end{array}$} & Judul & Geng Wahyudi Dukung Rendra \\
\hline & Lead & $\begin{array}{l}\text { Setelah menarik dukungannya dari Dewanti Rumpoko-Masrifah Hadi, } \\
10 \text { Agustus lalu, kini Geng Wahyudi terang-terangan mendukung } \\
\text { pasangan nomor urut satu Rendra Kresna-Sanusi. }\end{array}$ \\
\hline & Latar informasi & $\begin{array}{l}\text { Tidak banyak alasan yang dikemukakan oleh Geng, mengapa akhirnya } \\
\text { mendukung Rendra yang notabene menjadi rivalnya pada pilbup } 2010 \text {. } \\
\text { Dia hanya mengatakan bahwa Rendra masih menjadi sosok yang punya } \\
\text { kapasitas memimpin Kabupaten Malang. Kami tak lihat siapa } \\
\text { orangnya,tapi lebih pada sosok. }\end{array}$ \\
\hline & Kutipan sumber & $\begin{array}{l}\text { Rendra sendiri menyambut baik dukungan yang diberikan oleh Geng. } \\
\text { Menurutnya, dukungan tersebut sekaligus mewakili suara organisasi } \\
\text { kepemudaan dan masyarakat luas. "Terima kasih atas kepercayaannya. } \\
\text { Mohon doanya," kata Rendra } \\
\text { Ketua DPC PKB Kabupaten Malang Abdulrahman semakin yakin } \\
\text { bahwa Rendra-Sanusi akan memenangi pilbup 2015. "Saya kira semua } \\
\text { masyarakat tahu kapasitas seorang Geng Wahyudi," }\end{array}$ \\
\hline & $\begin{array}{l}\text { Pernyataan/ opini } \\
\text { penulis }\end{array}$ & $\begin{array}{l}\text { Kilas balik sedikit ke belakang, Geng seperti diketahui pernah menjadi } \\
\text { kader loyal PDIP. Hingga kemudian, DPP PDIP memecat Geng, lewat } \\
\text { surat keputusan (SK) bernomor } 425 / \mathrm{KPTS} / \mathrm{DPP} / \mathrm{III} / 2015 \text { pada } 12 \text { Maret } \\
\text { lalu. Geng dipecat sete-lah dianggap bertanggung jawab atas keributan } \\
\text { dalam konferensi cabang (konfercab) PDIP di Hotel Utami Sidoarjo, } 11 \\
\text { Maret lalu. } \\
\text { Namun, meski sudah dipecat, Geng ternyata masih menunjukkan } \\
\text { loyalitas kepada PDIP. Salah satunya dengan menerima tanggungjawab } \\
\text { sebagai ketua tim relawan peme-nangan Dewanti-Masrifah. Tapi di } \\
\text { tengah jalan, tepatnya pada } 10 \text { Agustus, Geng mundur. Alasannya, DPC } \\
\text { PDIP dianggap tidak punya komitmen untuk memenangkan pilbup. } \\
\text { Ketika mengumumkan pengunduran diri, sekaligus membuka peluang } \\
\text { mengalihkan dukungan kepada Rendra-Sanusi. }\end{array}$ \\
\hline & Penutup & $\begin{array}{l}\text { DPC PDIP dianggap tidak punya komitmen untuk memenangkan } \\
\text { pilbup. Ketika mengumumkan pengunduran diri, sekaligus membuka } \\
\text { peluang mengalihkan dukungan kepada Rendra-Sanusi. }\end{array}$ \\
\hline \multirow{5}{*}{$\begin{array}{l}\text { STRUKTUR } \\
\text { SKRIP }\end{array}$} & What & $\begin{array}{l}\text { Geng Wahyudi terang-terangan mendukung pasangan nomor urut satu } \\
\text { Rendra Kresna-Sanusi. }\end{array}$ \\
\hline & Who & Geng Wahyudi \\
\hline & When & $1 / 10 / 2015$ \\
\hline & Where & Desa Karangduren, Kecamatan Pakisaji \\
\hline & Why & DPC PDIP dianggap tidak punya komitmen untuk memenangkan \\
\hline
\end{tabular}

Rahadi. Pembingkaian Berita Pada Media Lokal / 03/ Vol.5. No. 1. Tahun 2017 


\begin{tabular}{|c|c|c|}
\hline \multicolumn{3}{|c|}{ 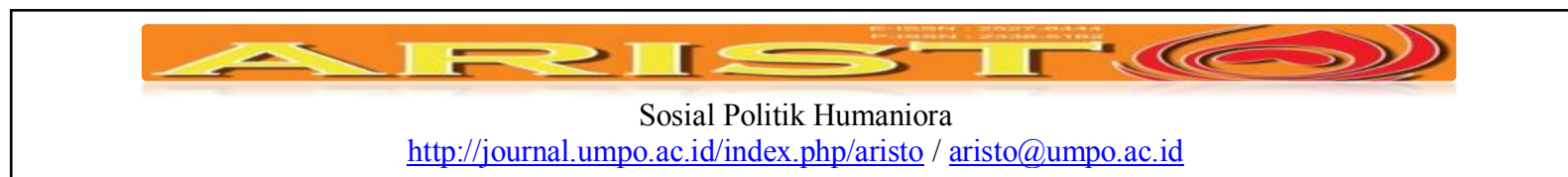 } \\
\hline & & pilbup. \\
\hline & How & membuka peluang mengalihkan dukungan kepada Rendra-Sanusi \\
\hline $\begin{array}{l}\text { Struktur } \\
\text { Tematik }\end{array}$ & $\begin{array}{l}\text { Paragraph, } \\
\text { proposisi, kalimat, } \\
\text { hubungan antar } \\
\text { kalimat }\end{array}$ & $\begin{array}{l}\text { Pada pemberitaan ini terdapat sub judul Disampaikan Dalam Acara } \\
\text { Peringatan Hari Kesaktian Pancasila, sehingga meng-isyaratkan bahwa } \\
\text { apa yang dilakukannya ini merupakan bentuk dari kesetiaan kepada } \\
\text { pancalisa. Berita ini terdiri dari Sembilan paragraph, paragaraf awal } \\
\text { dimulai dengan kalimat tentang geng wahyudi yang mendukung } \\
\text { pasangan rendra kresna-sanusi. Pada paragraph kedua dan ketiga } \\
\text { wartawan mencoba mengungkapkan alasan penarikan dukungan geng } \\
\text { wahyudi kepada pasangan dewanti-masrifah. Paragraph keempat } \\
\text { wartawan ingin menunjukan para pengikut Geng Wahyudi yang akan } \\
\text { setia dengan pandangan politiknya. Paragraph keenam wartawan } \\
\text { mencoba memasukkan opininya yang terlihat mendukung } \\
\text { (membenarkan apa yang dilakukan oleh Geng Wahyudi). }\end{array}$ \\
\hline $\begin{array}{l}\text { Struktur } \\
\text { Retoris }\end{array}$ & $\begin{array}{l}\text { Kata, idiom, } \\
\text { gambar/foto, } \\
\text { grafik }\end{array}$ & $\begin{array}{l}\text { Pengunaan kata "Kami tak lihat siapaorangnya, tapi lebih pada sosok } \\
\text { yang kami anggap pantas dan mampu memimpin kabupaten, kalimat ini } \\
\text { merujuk pada sosok Rendra Kresna-Sanusi. } \\
\text { Namun, meski sudah dipecat, Geng ternyata masih menunjuk-kan } \\
\text { loyalitas kepada PDIP, wartawan menyiratkan bahwa sosok Geng } \\
\text { Wahyudi adalah sosok yang loyalis dalam berpendirian selama itu demi } \\
\text { kepentingan negara (Pancasila), dan ini dikuatkan dengan } \\
\text { pernyataannya yang dijadikan sebagai kalimat penutup berita "DPC } \\
\text { PDIP dianggap tidak punya komitmen untuk memenangkan pilbup" } \\
\text { Pada berita ini diperlihatkan foto antara Geng dan Rendra sedang } \\
\text { berjabat tangan dengan gaya komando. }\end{array}$ \\
\hline
\end{tabular}

\section{Berita tanggal 2 Oktober 2016}

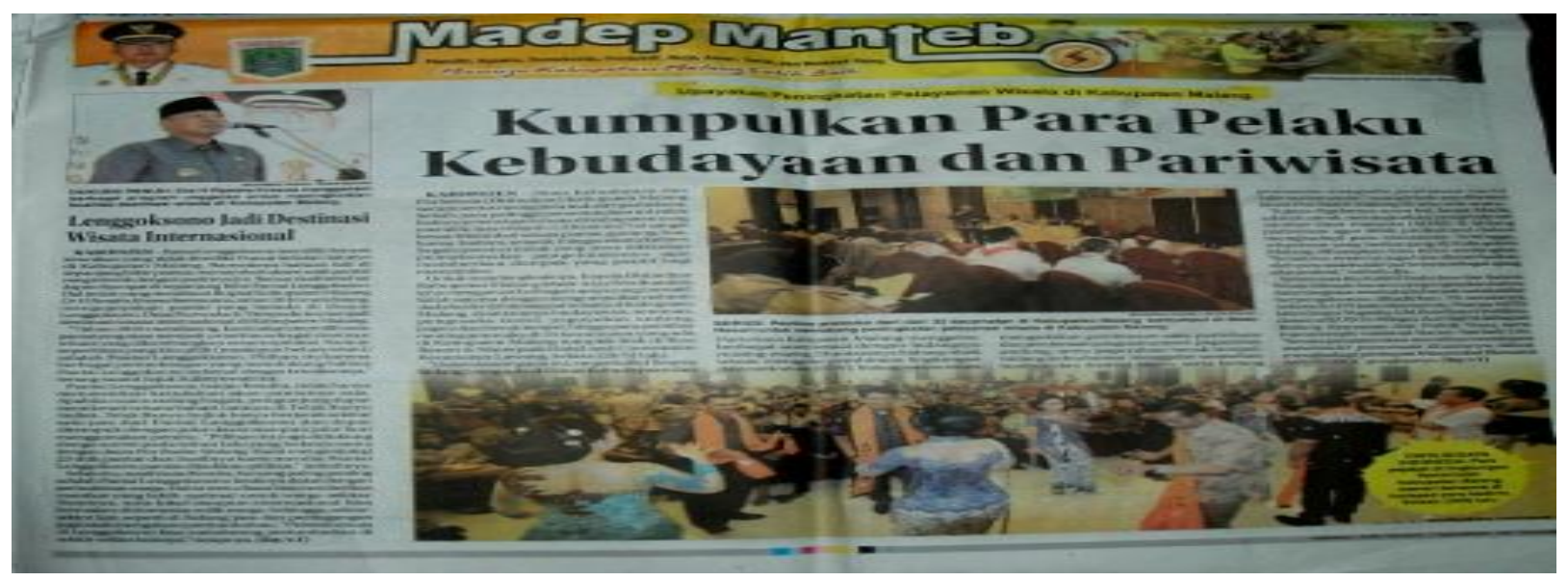

\section{Judul berita: Lenggoksono Jadi Destinasi Wisata Internasional \\ Isi Berita:}

Kabupaten - Pantai Lenggoksono memiliki banyak keunikan yang tidak dimiliki pantai selatan lainnya di kabupaten Malang. Banyaknya batuan kali disepanjang bibir pantai, menambah aksen unik pantai yang identik dengan pasirnya ini. Batuan kali tersebut dapat dijumpai di sepanjang bibir Pantai Lenggoksono. Hal inilah yang membuat Bupati Kabupaten Malang Dr H Rendra Kresna berencana, tahun 2016 mendatang, mengupayakan pantai yang berada di dusun Lenggoksono, Desa Purwodadi, Tirtoyudo ini menjadi destinasi wisata internasional di Kabupaten Malang. "Tahun 2016 mendatang, kami akan memilih satu pantai yang akan menjadi prioritas sebagai destinasi wisata yang dikembangkan secara optimal. Namun seperti yang kita pilih (meskipun belum resmi) adalah pantai Lenggoksono. Pilihan itu 


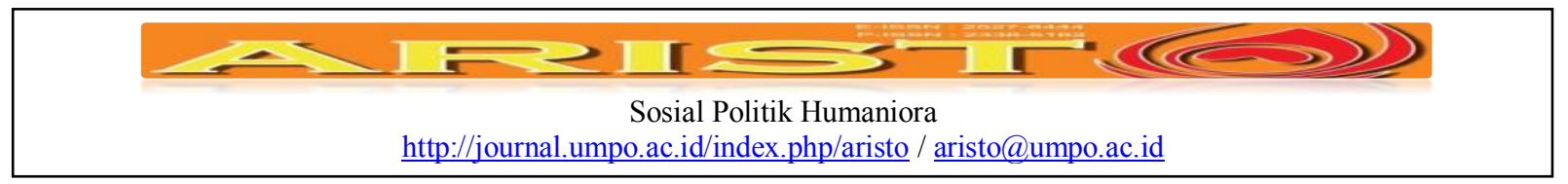

karena berbagai pertimbangan yang mendukung bahwa Pantai Lenggoksono yang terkenal akan keunikannya", terang suami jujuk Sulisyowati ini. Pantai Lenggoksono, lanjut Rendra, tidak hanya menawarkan keindahan akan pantainya saja. Apabila cuaca sedang bagus, pengunjung dapat dapat menikmati wisata bahari lainnya di Teluk banyu anjlok. Teluk Banyu Anjlok hanya berjarak sekitar satu jam dari Pantai Lenggoksono dan dapat ditempuh dengan jalur darat maupun laut menggunakan perahu. "pilihan ini juga didukung dengan survei pada tahun lalu yang bekerja sama dengan Jawa Pos Radar Malang. Kami mengunjungi 23 titik pantai dan hasilnya kami menilai pantai Lenggoksono pantas dijadikan pilihan," imbuhnya. Selain itu, masih kata Rendra, hal yang paling penting adalah Pantai Lenggoksosno letaknya dekat dengan pemukiman warga. Hal ini tentu dirasa bisa memberikan manfaat yang lebih optimal untuk warga sekitar. Nantinya, turis lokal maupun internasional bisa bermalam di homestay milik warga. Sehingga sektor-sektor lain seperti di bidang jasa dan perdagangan juga akan mengalami pertumbuhan. "potensi wisata di Lenggoksono bisa mendorong pertumbuhan di sektor-sektor lainnya, 'tutupnya. (fay/c1)

\section{Tabel 4}

Analisis Framing Pan Dan Kosicki Berita Diatas

\begin{tabular}{|c|c|c|}
\hline $\begin{array}{l}\text { Perangkat } \\
\text { Framing }\end{array}$ & $\begin{array}{c}\text { Unit } \\
\text { pengamatan } \\
\end{array}$ & Hasil pengamatan \\
\hline \multirow{6}{*}{$\begin{array}{l}\text { STRUKTUR } \\
\text { SINTAKSIS }\end{array}$} & Judul & Lenggoksono Jadi Destinasi Wisata Internasional \\
\hline & Lead & $\begin{array}{l}\text { Pantai Lenggoksono memiliki banyak keunikan yang tidak dimiliki } \\
\text { pantai selatan lainnya di kabupaten Malang }\end{array}$ \\
\hline & Latar informasi & $\begin{array}{l}\text { Pantai Lenggoksono, lanjut Rendra, tidak hanya menawarkan } \\
\text { keindahan akan pantainya saja. Apabila cuaca sedang bagus, } \\
\text { pengunjung dapat dapat menikmati wisata bahari lainnya di Teluk } \\
\text { banyu anjlok }\end{array}$ \\
\hline & Kutipan sumber & $\begin{array}{l}\text { Bupati Malang Dr H Rendra Kresna } \\
\text { "Tahun } 2016 \text { mendatang, kami akan memilih satu pantai yang akan } \\
\text { menjadi prioritas sebagai destinasi wisata yang dikembangkan secara } \\
\text { optimal. Namun seperti yang kita pilih (meskipun belum resmi) adalah } \\
\text { pantai Lenggoksono. Pilihan itu karena ber-bagai pertimbangan yang } \\
\text { mendukung bahwa Pantai Lenggoksono yang terkenal akan } \\
\text { keunikannya", } \\
\text { "pilihan ini juga didukung dengan survei pada tahun lalu yang bekerja } \\
\text { sama dengan Jawa Pos Radar Malang. Kami mengunjungi } 23 \text { titik } \\
\text { pantai dan hasilnya kami menilai pantai Lenggoksono pantas dijadikan } \\
\text { pilihan. } \\
\text { "Potensi wisata di Lenggoksono bisa mendorong pertumbuhan di } \\
\text { sektor-sektor lainnya }\end{array}$ \\
\hline & $\begin{array}{l}\text { Pernyataan/ opini } \\
\text { penulis }\end{array}$ & \\
\hline & Penutup & $\begin{array}{l}\text { "Pantai Lenggoksosno dekat dengan pemukiman warga. Hal ini tentu } \\
\text { dirasa bisa mem-berikan manfaat yang lebih optimal untuk warga } \\
\text { sekitar. Nantinya, turis lokal maupun internasional bisa bermalam di } \\
\text { homestay milik warga. Sehingga sektor-sektor lain seperti di bidang } \\
\text { jasa dan perdagangan juga akan mengalami pertumbuhan. }\end{array}$ \\
\hline \multirow{5}{*}{$\begin{array}{l}\text { STRUKTUR } \\
\text { SKRIP }\end{array}$} & What & $\begin{array}{l}\text { Pantai Lenggoksono akan dijadi Destinasi Wisata Internasional oleh } \\
\text { pemerintah kabupaten Malang. }\end{array}$ \\
\hline & Who & Bupati Malang, Dr H Rendra Kresna \\
\hline & When & $\begin{array}{l}\text { Tidak ada informasi tentang waktu dari wartawan saat membuat berita } \\
\text { ini. Entah itu terkait dengan lokasi wawancara dengan narasumber } \\
\text { ataukah waktu saat mewawancarai. }\end{array}$ \\
\hline & Where & Dusun Lenggoksono, Desa Purwodadi, Tirtoyudo \\
\hline & Why & Pantai Lenggoksosno letaknya dekat dengan pemu-kiman warga. Hal \\
\hline
\end{tabular}

Rahadi. Pembingkaian Berita Pada Media Lokal / 03/ Vol.5. No. 1. Tahun 2017 


\begin{tabular}{|l|l|l|}
\hline \multicolumn{1}{|c|}{} & \multicolumn{1}{|c|}{$\begin{array}{l}\text { Sosial Politik Humaniora } \\
\text { http://journal.umpo.ac.id/index.php/aristo / aristo@umpo.ac.id }\end{array}$} \\
\hline \multirow{2}{*}{ Struktur Tematik } & $\begin{array}{l}\text { ini tentu dirasa bisa memberikan manfaat yang lebih optimal untuk } \\
\text { warga sekitar. }\end{array}$ \\
\cline { 2 - 3 } & $\begin{array}{l}\text { Paragraph, } \\
\text { proposisi, } \\
\text { kalimat, } \\
\text { hubungan antar } \\
\text { kalimat }\end{array}$ & $\begin{array}{l}\text { Paragraf-paragraf yang ada di dalam berita ini hamper sebagian besar } \\
\text { merupakan penjabaran dari wartawan atas apa yang sudah dikatakan } \\
\text { oleh narasumber. Sehingga banyaknya kutipan langsung maupun tidak } \\
\text { langsung menjadi bagian terbanyak dalam penulisan berita ini. }\end{array}$ \\
\hline $\begin{array}{l}\text { Kata, idiom, } \\
\text { gambar/foto, } \\
\text { grafik }\end{array}$ & $\begin{array}{l}\text { Penggunaan kalimat yang bersifat future tense (Tahun 2016 } \\
\text { mendatang) sangat kontras dengan judul berita yang dibuat. Wartawan } \\
\text { seolah-olah ingin mengatakan bahwa kebijakan itu sudah dilakukan } \\
\text { (dengan mengacu pada judul berita). } \\
\text { Foto yang dimuat oleh Radar Malang hanya memperlihatkan Rendra } \\
\text { Kresna saat menjadi pembicara, tanpa diketahui itu dalam acara apa. }\end{array}$ \\
\hline
\end{tabular}

\section{Berita tanggal 3 Oktober 2016}
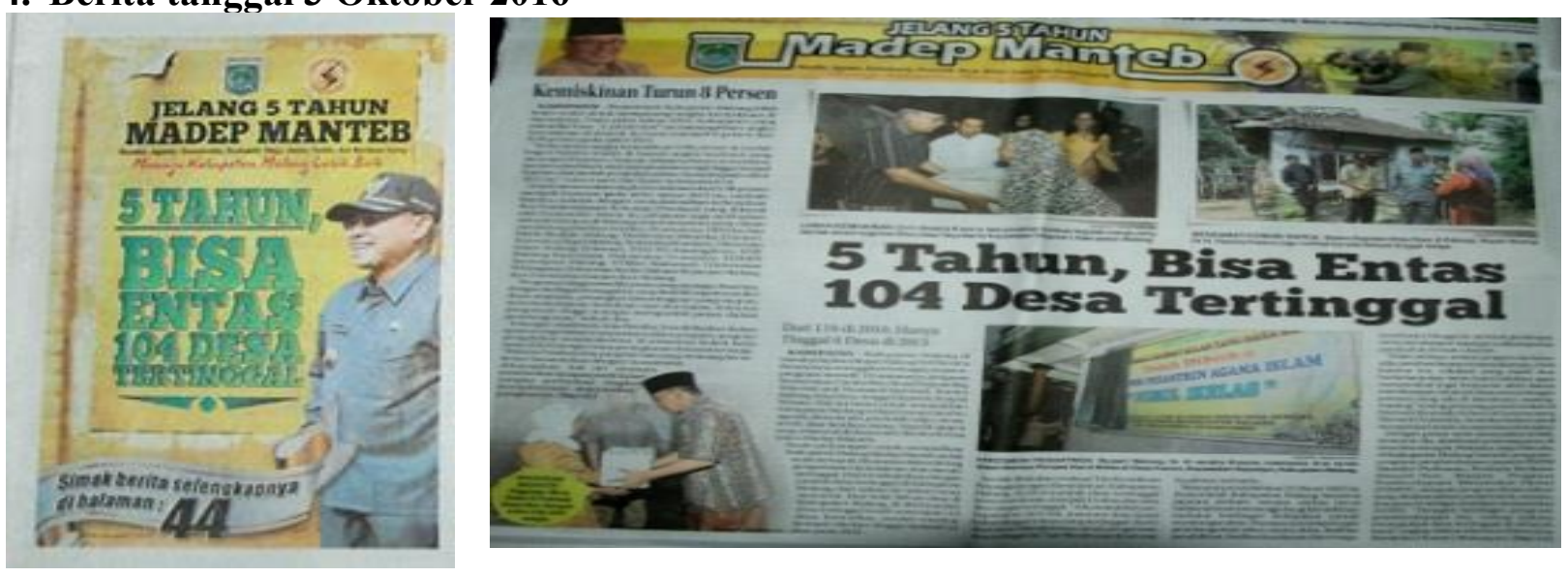

\section{Judul berita: 5 Tahun Bisa Entas 104 Desa Tertinggal \\ Isi berita:}

Kabupaten- Kabupaten Malang dibawah pimpinan Bupati Malang Dr H Rendra Kresna terus menggeber berbagai program-program inovatif. Diantaranya profram sutra emas, Contra war, Emas (expanding Material and Neonatal Survival), kantor keliling, bina desa, hingga ekspansi tempat wisata. Hal ini tentu untuk menjadikan kabupaten Malang wilayah mandiri, agamis, demokratis, produktif, maju, aman, tertib, dan berdaya saing. Seprti jargon yang selama ini diinisiasi oleh rendra kresna yakni Madep Manteb. Buah perjuangan untuk menjadikan kabupaten Malang Madep Manteb sudah mulai terwujud, khususnya dalam bidang pengentasan kemiskinan dan daerah tertinggal. Hal ini dibuktikan dengan jumlah desa tertinggal di kabupaten Malang dari tahun ke tahun terus menurun. Dari total 390an desa di kabupaten Malang, di tahun 2010 jumlah desa tertinggal masih mencapai 110 desa. Kemudian jumlah tersebut berhasil ditekan hingga menjadi 51 desa pada 2012. Setelah dilakukan evaluasi tim koordinasi penanggulangan kemiskinan kabupaten Malang, di 2014 jumlah desa tertinggal menyusut drastis menjadi 15 desa dan satu desa sangat tertinggal. Alhammdulillah per September 2015 ini, menurut data kami hanya tinggal 6 desa yang tertinggal. Kami akan terus bekerja keras untuk pengentasan desa tertinggal ini" ujar rendra saat dihubungi by phone kemarin. Menurut pria kelahiran 22 maret 1962 ini, pemerintah kabupaten Malang bersama jajaran terkait, secara serius teruys berkomitmen menaggulangi kemiskinan melalui berbagai kebijakan untuk membangun desa. Diantaranya mempercepat pembangunan jalan desa, fasilitas pendidikan, fasilitas kesehatan dan tenaga kesehatan himgga ke pelosok pedesaaan, dan membuka peluang usaha bagi masyarakat. "Intinya semua program harus ada proses pemberdayaan masayarakat. Karena itu, edukasi yang massif dan berkelanjutan terus kami 


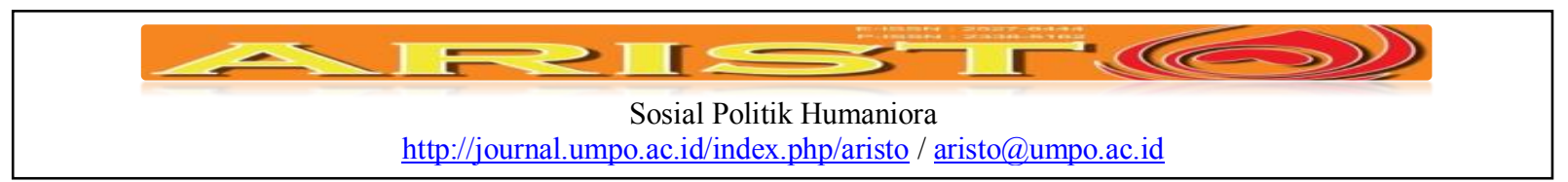

lakukan agar masyarakat juga berperan aktif dalam membangun ekonomi desa sesuai dengan potensi yang ada di daerahnya masing-masing” terang pria yang pernah kuliah di Harvard Kennedy School of Government, Harvad University, Amerika Serikat untuk mempelajari system ekonomi daerah tersebut. Dengan peran serrta inilah, menurut dia akslerasi pembangunan di desa bisa tercapai. Makanya, lanjut rendra di kabupaten malang banyak program program pemberdayaan seperti PNPM mandiri pedesaan, posdaya berbasis Masjid - Non Masjid, program pemberdayaan masyarakat pantai (P2MPP), maupun lintas sektor yang dilaksanakan pemerintah, swasta maupun LSM. "Dengan berbagai program pemberdayaan ini, cukup sukses memajukan desa tertinggal di wilayah kami" ungkap doctor alumnus Universitas Merdeka (Unmer) Malang ini. (Fay/c1)

\section{Tabel 5}

\section{Analisis Framing Pan Dan Kosicki Berita Diatas}

\begin{tabular}{|c|c|c|}
\hline \\
\hline $\begin{array}{c}\text { Perangkat } \\
\text { Framing }\end{array}$ & Unit pengamatan & Hasil pengamatan \\
\hline \multirow{6}{*}{$\begin{array}{l}\text { STRUKTUR } \\
\text { SINTAKSIS }\end{array}$} & Judul & 5 Tahun Bisa Entas 104 Desa Tertinggal \\
\hline & Lead & $\begin{array}{l}\text { Kabupaten- Kabupaten Malang dibawah pimpinan Bupati } \\
\text { Malang Dr H Rendra Kresna terus menggeber berbagai } \\
\text { program-program inovatif. }\end{array}$ \\
\hline & Latar informasi & $\begin{array}{l}\text { Dari total 390an desa di kabupaten Malang, di tahun } 2010 \\
\text { jumlah desa tertinggal masih mencapai } 110 \text { desa. Kemudian } \\
\text { jumlah tersebut berhasil ditekan hingga menjadi } 51 \text { desa pada } \\
2012 \text {. }\end{array}$ \\
\hline & Kutipan sumber & $\begin{array}{l}\text { Bupati Malang Dr H Rendra Kresna } \\
\text { “. Alhammdulillah per September } 2015 \text { ini, menurut data } \\
\text { kami hanya tinggal } 6 \text { desa yang tertinggal. Kami akan terus } \\
\text { bekerja keras untuk pengentasan desa tertinggal ini” } \\
\text { "intinya semua program itu harus ada pemberdayaan } \\
\text { masyarakatnya. Oleh karena itu, edukasi yang massif dan } \\
\text { berkelanjutan terus kami lakukan agar masyarakat juga } \\
\text { berperan aktif dalam membangun ekonomi desa sesuai } \\
\text { dengan potensi yang ada di daerahnya masing-masing" } \\
\text { "Dengan berbagai program pemberdayaan ini, cukup sukses } \\
\text { memajukan desa tertinggal di wilayah kami" }\end{array}$ \\
\hline & Pernyataan/ opini penulis & $\begin{array}{l}\text { Buah perjuangan untuk menjadikan kabupaten malang Madep } \\
\text { Manteb sudah mulai terwujud, khususnya dalam bidang } \\
\text { pengentasan kemiskinan dan daerah tertinggal. Hal ini } \\
\text { dibuktikan dengan jumlah desa tertinggal di kabupaten } \\
\text { Malang dari tahun ke tahun terus menurun. Dari total 390an } \\
\text { desa di kabupaten Malang, di tahun } 2010 \text { jumlah desa } \\
\text { tertinggal masih mencapai } 110 \text { desa. Kemudian jumlah } \\
\text { tersebut berhasil ditekan hingga menjadi } 51 \text { desa pada } 2012 \text {. }\end{array}$ \\
\hline & Penutup & $\begin{array}{l}\text { "Dengan berbagai program pemberdayaan ini, cukup sukses } \\
\text { memajukan desa tertinggal di wilayah kami" ungkap doctor } \\
\text { alumnus Universitas Merdeka (Unmer) Malang ini. }\end{array}$ \\
\hline \multirow{5}{*}{$\begin{array}{c}\text { STRUKTUR } \\
\text { SKRIP }\end{array}$} & What & Pengentasan desa tertinggal \\
\hline & Who & Bupati Malang, Dr H Rendra Kresna \\
\hline & When & $2 / 10 / 2015$ \\
\hline & Where & \\
\hline & Why & $\begin{array}{l}\text { Dari total 390an desa di kabupaten Malang, di tahun } 2010 \\
\text { jumlah desa tertinggal masih mencapai } 110 \text { desa. Kemudian } \\
\text { jumlah tersebut berhasil diturunkan menjadi } 52 \text { Desa pada } \\
2012 \\
\text { Setelah dilakukan evaluasi tim koordinasi penanggu-langan }\end{array}$ \\
\hline
\end{tabular}

Rahadi. Pembingkaian Berita Pada Media Lokal / 03/ Vol.5. No. 1. Tahun 2017 


\begin{tabular}{|c|c|c|}
\hline \multicolumn{3}{|c|}{ 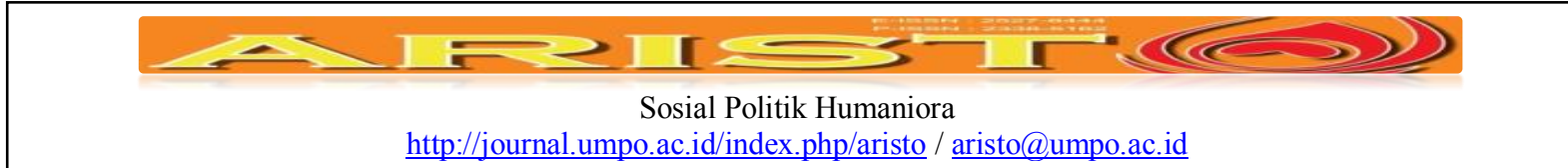 } \\
\hline \multicolumn{3}{|c|}{\begin{tabular}{l|l} 
& $\begin{array}{l}\text { kemiskinan kabupaten Malang, di } 2014 \text { jumlah desa tertinggal } \\
\text { menyusut drastis menjadi 15 desa dan satu desa sangat } \\
\text { tertinggal. Alhammdulillah per September } 2015 \text { ini, menurut } \\
\text { data kami hanya tinggal } 6 \text { desa yang tertinggal. }\end{array}$ \\
\end{tabular}} \\
\hline & How & $\begin{array}{l}\text { Di kabupaten malang banyak program program pemberdayaan } \\
\text { seperti PNPM mandiri pedesaan, posdaya berbasis Masjid - } \\
\text { Non Masjid, program pemberdayaan masyarakat pantai } \\
\text { (P2MPP), maupun lintas sektor yang dilaksanakan } \\
\text { pemerintah, swasta maupun LSM. }\end{array}$ \\
\hline Struktur Tematik & $\begin{array}{l}\text { Paragraph, proposisi, } \\
\text { kalimat, hubungan antar } \\
\text { kalimat }\end{array}$ & $\begin{array}{l}\text { Di awal kalimat wartawan menuliskan program - program } \\
\text { yang sudah dilakukan oleh Rendra Kresna. Selanjutnya } \\
\text { diperkuat dengan data dari tim koordinasi penanggulangan } \\
\text { kemiskinan kabupaten malang. Hal ini tentu wartawan ingin } \\
\text { memberikan penegasan dalam pemberitaannya bahwa } \\
\text { program yang dilakukan benar benar berhasil. Pada paragraph } \\
\text { selanjutnya wartawan menuliskan latar belakang pendidikan } \\
\text { Rendra Kresna yang bertujuan untuk membuktuikan bahwa } \\
\text { dia adalah orang yang benar benar berkompeten di bidangnya. }\end{array}$ \\
\hline Struktur Retoris & $\begin{array}{l}\text { Kata, idiom, gambar/foto, } \\
\text { grafik }\end{array}$ & $\begin{array}{l}\text { Gambar tentang program Madep Manteb yang ditaruh di } \\
\text { halaman depan Radar Malang. Setting layout ini dibuat guna } \\
\text { memudahkan para pembaca untuk mengetahui berita yang } \\
\text { lebih lengkapnya dihalaman yang sudah ditentukan (guiding) } \\
\text { Pemberitaan tentang program madep manteb di halaman } 44 \\
\text { dengan ukuran pemberitaan seperempat halaman Koran }\end{array}$ \\
\hline
\end{tabular}

\section{Berita tanggal 5 Oktober 2016}
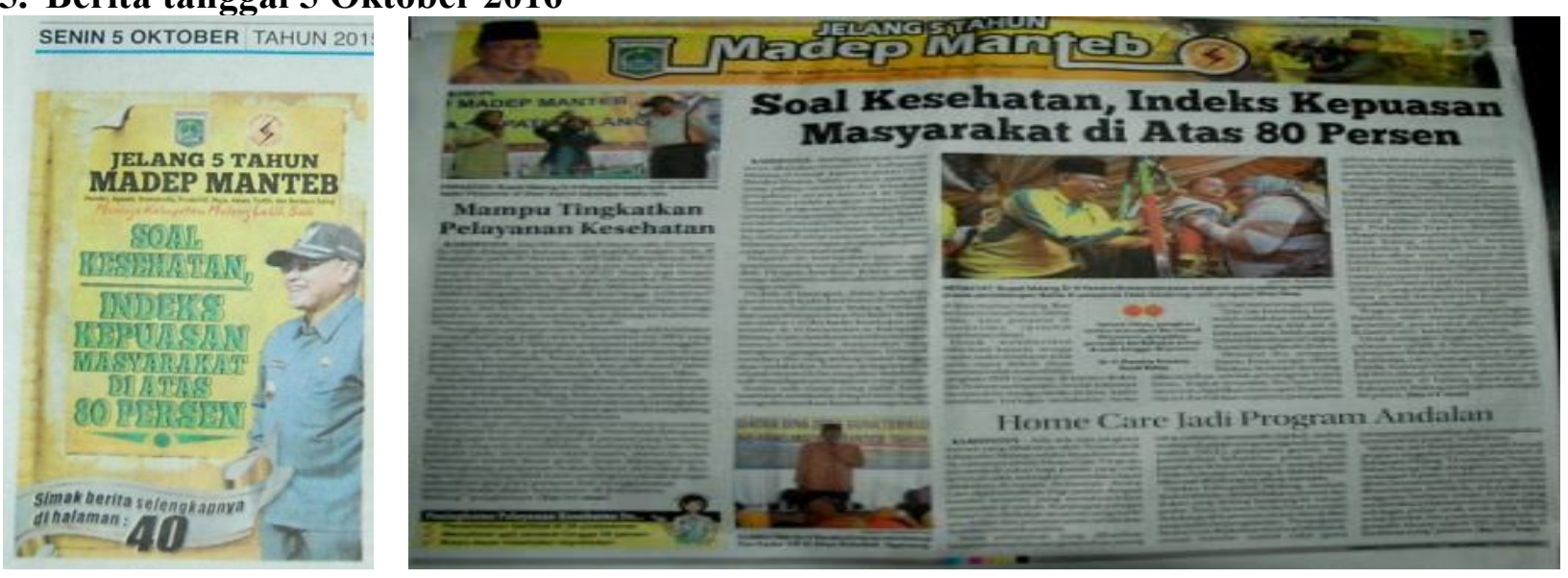

\section{Judul berita: Soal Kesehatan Indeks Kepuasan Masyarakat di Atas 80 Persen \\ Isi berita:}

Kabupaten - berbagai program inovasi terus dilakukan pemerintah kabupaten malang di bawah kepemimpinan Dr H Rendra Kresna. Salah satunya, gebrakan yang paling menonjol dan mendapatka pengakuan secara nasional di bidang kesehatan adalah program Sutera Emas. Terbukti program itu telah mengantarkan kabupaten malang yang memiliki visi madep manteb berhasil meraih otonomi awards 2013 kategori pelayanan kesehatan. Bukan hanya itu, bahkan ditahun yang sama, kabupaten malang juga mendapatkan penghargaan grand kategory pelayanan publik. Program itu merupakan upagar agar kesehatan setiap warga bisa terdeteksi sejak dini. Dengan demikian, belum sampai warga sakit parah, sudah ada tindakan dari tenaga medis. Praktik di lapangan, Dinas kesehatan membentuk kader kesehatan di setiap RT diseluruh kabupaten Malang. Berdasarkan dat yang dihimpun Jawa Pos Radar Malang ada sekitar 12 ribu kader kesehatan yang tersebar di 33 kecamatan se-kabupaten Malang. 


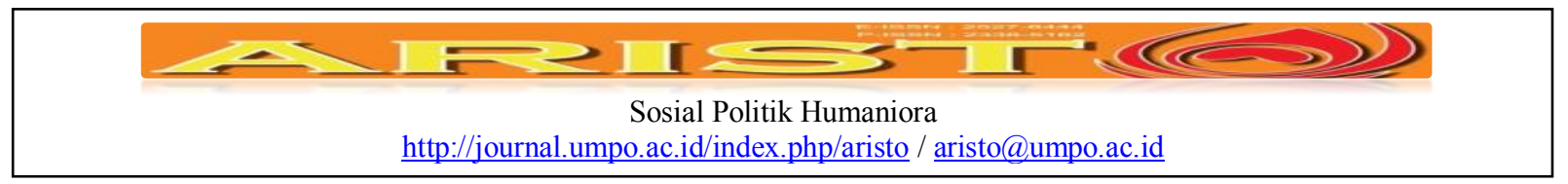

Kader kesehatan tersebut bertugas mencari informasi masyarakat yang mengalami gangguan kesehatan. Termasuk mendata ibu yang hamil dan yang akanmelahirkan sulit mendapatkan penanganan yang cepat. Ketika ada yang sakit, kader kesehatan melakukan jemput bola dengan menginforma-sikan kepada tenaga medis di desa masing-masing. Bisa ke mantra kesehatan, bidan desa, atau perawat di pondeskes (pondok kesehatan desa). Untuk memberikan informasi kepada tenaga medis, kader kesehatan tidak perlu repot. Sebab Dinaskesehatan telah menyediakan program sms gate way dikantor Dinkes dan puskesmas Kepanjen. Setelah informasi itu masuk ke tenaga medis di desa kaderbertugas melakukan home visit bersama tenaga medis. "dari sisi kesehatan, kami sudah melakukan terobosan-terobosan yang tidak ada di kabupaten lain. Salah satunya melalui sutera emas ini, ungkap Bupati Malang Rendra Kresna. Menurut dia, program Suter Emas sangat efektif. Bahkan berdasarkan data yang dikumpulkan, setelah ada program Sutera Emas, tingkat kematian ibu hamil bisa menurun signifikan mencapai 20\% hal ini disebabkan cepatnya penanganan oleh tim medis setelah mendapatkan informasi dari kader kesehatan di setiap RT. Bahkan penyakit berbahayaseperti demam berdarah menurun drastic hingga 40 persen. "program suter emas ini sangat bagus. Pasalnya telah menjadi percontohan bagi pemerintah pusat untuk dikembangkan didaerah lain. Untuk mengukur tingkat keberhasilan pelayanan public di bidang kesehatan, kabupaten Malang bekerja sama dengan pihak ketiga, yakni lembaga survey layanan public nasional Mahadewa. Hasilnya per Juli 2015, diketahui bahwa tingkat kepuasan masyarakat di bidang kesehatan di kabupaten Malang meningkat mencapai 80 persen. (fay/c1/mas)

\begin{tabular}{|c|c|c|}
\hline \multicolumn{3}{|c|}{$\begin{array}{c}\text { Tabel } 6 \\
\text { Analisis Framing Pan Dan Kosicki Berita Diatas }\end{array}$} \\
\hline $\begin{array}{c}\text { Perangkat } \\
\text { Framing }\end{array}$ & Unit pengamatan & Hasil pengamatan \\
\hline \multirow{8}{*}{$\begin{array}{l}\text { STRUKTUR } \\
\text { SINTAKSIS }\end{array}$} & Judul & Soal Kesehatan Indeks Kepuasan Masyarakat di Atas 80 Persen \\
\hline & Lead & $\begin{array}{l}\text { Kabupaten- berbagai program inovasi terus dilakukan pemerintah } \\
\text { kabupaten malang di bawah kepemimpinan Dr H Rendra Kresna }\end{array}$ \\
\hline & Latar informasi & $\begin{array}{l}\text { Visi madep manteb berhasil meraih otonomi awards } 2013 \text { kategori } \\
\text { pelayanan kesehatan. Program itu merupakan upagar agar } \\
\text { kesehatan setiap warga bisa terdeteksi sejak dini. Dengan } \\
\text { demikian, belum sampai warga sakit parah, sudah ada tindakan } \\
\text { dari tenaga medis. Praktik di lapangan, dinas kesehatan } \\
\text { membentuk kader kesehatan di setiap RT diseluruh kabupaten } \\
\text { malang. }\end{array}$ \\
\hline & Kutipan sumber & $\begin{array}{l}\text { Bupati Malang Rendra Kresna } \\
\text { "dari sisi kesehatan, kami sudah melakukan terobosan-terobosan } \\
\text { yang tidak ada di Kabupaten lain. Salah satunya ya lewat Sutera } \\
\text { Emas ini" } \\
\text { "program suter emas ini sangat bagus. Pasalnya telah mencadi } \\
\text { percontohan bagi pemerintah pusat untuk dikembangkan di daerah } \\
\text { lain. }\end{array}$ \\
\hline & $\begin{array}{l}\text { Pernyataan/ opini } \\
\text { penulis }\end{array}$ & $\begin{array}{l}\text { Berdasarkan dat yang dihimpun Jawa Pos Radar Malang ada } \\
\text { sekitar } 12 \text { ribu kader kesehatan yang tersebar di } 33 \text { kecamatan se- } \\
\text { kabupaten malang. Kader kesehatan tersebut bertugas mencari } \\
\text { informasi masyarakat yang mengalami gangguan kesehatan. } \\
\text { Termasuk mendata ibu yang hamil dan yang akan melahirkan sulit } \\
\text { mendapatkan penanganan yang cepat. }\end{array}$ \\
\hline & Penutup & $\begin{array}{l}\text { Hasilnya per Juli 2015, diketahui bahwa tingkat kepuasan } \\
\text { masyarakat di bidang kesehatan di kabupaten malang meningkat } \\
\text { mencapai } 80 \text { persen }\end{array}$ \\
\hline & What & $\begin{array}{l}\text { Gebrakan yang paling menonjol dan mendapatkan pengakuan } \\
\text { secara nasional di bidang kesehatan yaitu program Sutera Emas }\end{array}$ \\
\hline & Who & Bupati Malang Rendra Kresna \\
\hline
\end{tabular}

Rahadi. Pembingkaian Berita Pada Media Lokal / 03/ Vol.5. No. 1. Tahun 2017 


\begin{tabular}{|c|c|c|}
\hline \multicolumn{3}{|c|}{$\begin{array}{l}\text { Sosial Politik Humaniora } \\
\text { http://journal.umpo.ac.id/index.php/aristo / } \underline{\text { aristo@umpo.ac.id }}\end{array}$} \\
\hline \multirow{4}{*}{$\begin{array}{l}\text { STRUKTUR } \\
\text { SKRIP }\end{array}$} & When & \\
\hline & Where & Kabupaten Malang \\
\hline & Why & $\begin{array}{l}\text { Program ini merupakan upagar agar kesehatan setiap warga bisa } \\
\text { terdeteksi sejak dini. Dengan demikian, belum sampai warga sakit } \\
\text { parah, sudah ada tindakan dari tenaga medis }\end{array}$ \\
\hline & How & $\begin{array}{l}\text { Dinas kesehatan membentuk kader kesehatan di setiap RT } \\
\text { diseluruh kabupaten malang. Kader kesehatan tersebut bertugas } \\
\text { mencari informasi masyarakat yang mengalami gangguan } \\
\text { kesehatan. Termasuk mendata ibu yang hamil dan yang akan } \\
\text { melahirkan sulit mendapatkan penanganan yang cepat. Ketika ada } \\
\text { yang sakit, kader kesehatan melakukan jemput bola dengan } \\
\text { menginfor-masikan kepada tenaga medis di desa masing-masing. } \\
\text { Bisa ke mantra kesehatan, bidan desa, atau perawat di pondeskes } \\
\text { (pondok kesehatan desa). Untuk memberikan informasi kepada } \\
\text { tenaga medis, kader kesehatan tidak perlu repot. Sebab dinas } \\
\text { kesehatan telah menyediakan program sms gateway dikantor } \\
\text { dinkes dan puskesmas kepanjen. Setelah informasi itu masuk ke } \\
\text { tenaga medis di desa, kader kesehatan bertugas melakukan home } \\
\text { visit bersama tenaga medis. }\end{array}$ \\
\hline Struktur Tematik & $\begin{array}{l}\text { Paragraph, proposisi, } \\
\text { kalimat, hubungan } \\
\text { antar kalimat }\end{array}$ & $\begin{array}{l}\text { Diawali dengan kalimat berbagai program inovasi yang sudah } \\
\text { dilakukan pemerintah kabupaten malang kemudian dilanjutkan } \\
\text { pada paragraph berikutnya yaitu menjelaskan program kesehatan } \\
\text { Sutera Emas yang sudah menda-patkan otonomi awards } 2013 . \\
\text { Hubungan antar kalimat dibuat saling menguatkan antara } \\
\text { kebijakan Bupati rendra kresna dengan program yang sudah } \\
\text { dilakukan oleh dinas kesehatan kabupaten Malang. }\end{array}$ \\
\hline Struktur Retoris & $\begin{array}{l}\text { Kata, idiom, } \\
\text { gambar/foto, grafik }\end{array}$ & $\begin{array}{l}\text { Foto Bupati Rendra Kresna menyapa warganya yang sedang } \\
\text { membantu proses penimbangan Balita di posyandu Desa } \\
\text { Sananrejo saat program Bina Desa. }\end{array}$ \\
\hline
\end{tabular}

\section{Berita tanggal 7 oktober 2015}

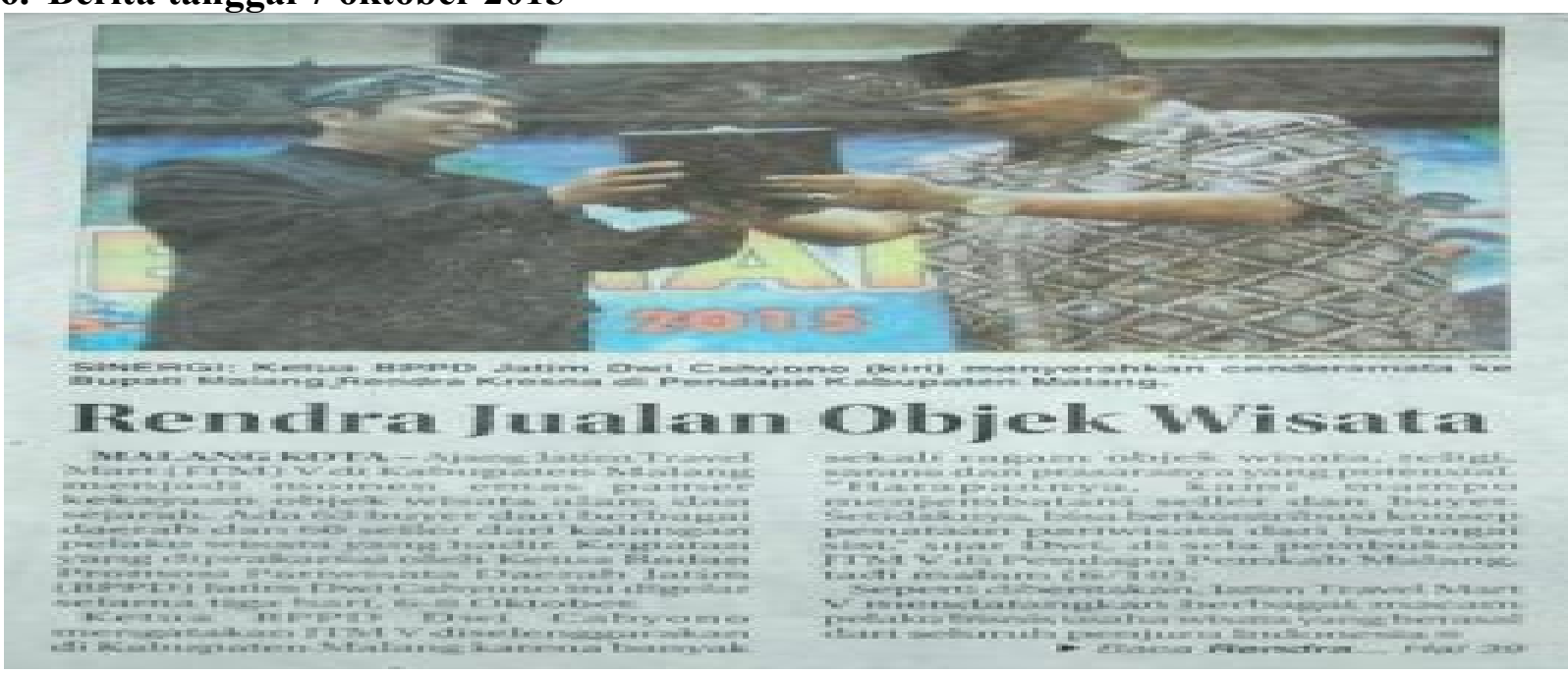

\section{Judul berita: Rendra Jualan Objek Wisata}

\section{Isi Berita:}

MALANG KOTA - Ajang Jatim Travel Mart (JTM) V di Kabupaten Malang menjadi momen emas pamer kekayaan objek wisata alam dan sejarah. Ada 63 buyer dari berbagai daerah dan 60 seller dari kalangan pelaku wisata yang hadir. Kegiatan yang diprakarsai oleh Badan Promosi Pariwisata Daerah Jatim 


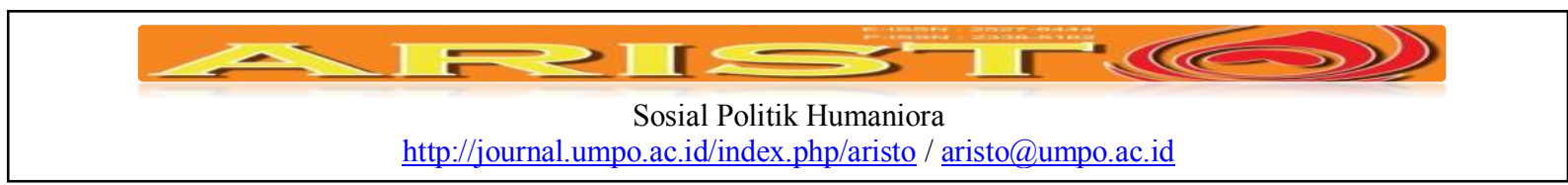

(BPPD) Jatim Dwi Cahyono ini digelar selama tiga hari, 6-8 Oktober. Ketua BPPD Dwi Cahyono mengatakan JTM $V$ diselenggarakan di Kabupaten Malang karena banyak sekali ragam objek wisata, religi, sarana dan prasaranya yang potensial. "Harapannya, kami mampu menjembatani seller dan buyer. Setidaknya, bisa berkontribusi konsep penataan pariwisata dari berbagai sisi," ujar Dwi, di sela pembukaan JTM V di Pendopo Pemkab Malang, tadi malam (6/10). Seperti diberitakan, Jatim Travel Mart $V$ mendatangkan berbagai macam pelaku bisnis usaha wisata yang berasal dari seluruh penjuru Indonesia. Serta memiliki pelanggan yang berpotensi besar membeli paket wisata di daerah Jawa Timur. Para buyer yang hadir sekitar 63 lembaga dari Lombok, Makassar, Jakarta, Sumatera hingga Bali. Selain itu, 60 lembaga pelaku wisata Jawa Timur juga dilibatkan. Mereka bertindak sebagai seller atau yang akan mempromosikan usahanya. Antara lain hotel, restoran, transportasi, pusat oleh-oleh, objek wisata, dan hal-hal yang berhubungan dengan pariwisata. Di antaranya berasal dari Malang, Surabaya, Pasuruan, Probolinggo. Jatim Travel Mart V ini dibuka oleh Bupati Malang Rendra Kresna dengan pemukulan gong. Acara pembukaan semakin meriah dengan music tradisional hingga tari-tarian. "Kabupaten Malang memang ingin lebih menjual potensi wisata yang jauh lebih baik lagi. Akhirnya program ini dapat terlaksana di sini," ujar Rendra, dalam sambutannya. Kepala Disbudpar Kabupaten Malang Made Arya Wedhantara menambahkan, sebenarnya sejak dari awal tahun sudah ada pembicaraan dengan kepala BPPD Jatim terkait dengan hal ini. Targetnya 2016 yaitu mampu menjual potensi wilayah laut dan desa wisata di Kabupaten Malang. "Sengaja kami pilih dua objek ini agar seluruh potensi wisata khususnya di daerah Malang selatan, lebih bisa dikenal" ujarnya. Paling tidak program ini mampu membuat objek wisata Kabupaten Malang. Praktis, meningkatkan wisatawan asing maupun lokal. Setidaknya, wisatawan terdongkrak 20 persen dari total target nasional menarik 20 juta wisatawan mancanegara. Salah satu buyer Hari Widariyanto dari Travel Werkudara Jogjakarta mengatakan baru mengetahui bahwa objek wisata di Kabupaten Malang sangat beragam. Selama ini, destinasi wisata favorit hanya Gunung Bromo dan Ijen. Dia mencontohkan travel miliknya sudah menjual paket promo khusus Malang. Tapi hanya objeknya monoton, setelah program ini, paket promo wisata akan ditambah lagi. "Banyak sekali wisata yang harus diketahui lebih banyak lagi," jelas Hari. Lebih lanjut Hari menambahkan, ada catatan yang harus diketahui pemerintah daerah untuk memacu kunjungan wisatawan. "Kalau di Jogya kan ada andong. Malang sebaiknya juga begitu. Budayanya lebih dikentalkan lagi," imbuhnya. (ega/lia)

\section{Tabel 7}

\section{Analisis Framing Pan Dan Kosicki Berita Diatas}

\begin{tabular}{|c|c|c|}
\hline $\begin{array}{c}\text { Perangkat } \\
\text { Framino }\end{array}$ & Unit pengamatan & Hasil pengamatan \\
\hline \multirow{4}{*}{$\begin{array}{l}\text { STRUKTUR } \\
\text { SINTAKSIS }\end{array}$} & Judul & Rendra Jualan Objek Wisata \\
\hline & Lead & $\begin{array}{l}\text { Ajang Jatim Travel Mart (JTM) V di Kabupaten Malang menjadi } \\
\text { momen emas pamer kekayaan objek wisata alam dan sejarah. }\end{array}$ \\
\hline & Latar informasi & $\begin{array}{l}\text { Jatim Travel Mart V mendatangkan berbagai macam pelaku bisnis } \\
\text { usaha wisata yang berasal dari seluruh penjuru Indonesia. Serta } \\
\text { memiliki pelanggan yang berpotensi besar membeli paket wisata di } \\
\text { daerah Jawa Timur. }\end{array}$ \\
\hline & Kutipan sumber & $\begin{array}{l}\text { Ketua BPPD Dwi Cahyono } \\
\text { "Harapannya, kami mampu menjembatani seller dan buyer. } \\
\text { Setidaknya, bisa berkontribusi konsep penataan pariwisata dari } \\
\text { berbagai sisi," } \\
\text { Kepala Disbudpar Kabupaten Malang Made Arya Wedhantara } \\
\text { "Sengaja kami pilih dua objek ini agar seluruh potensi wisata } \\
\text { khususnya di daerah Malang selatan, lebih bisa dikenal" } \\
\text { Hari Widariyanto dari Travel Werkudara Jogjakarta } \\
\text { "Selama ini, destinasi wisata favorit hanya Gunung Bromo dan Ijen. } \\
\text { Dia mencontohkan travel miliknya sudah menjual paket promo }\end{array}$ \\
\hline
\end{tabular}

Rahadi. Pembingkaian Berita Pada Media Lokal / 03/ Vol.5. No. 1. Tahun 2017 


\begin{tabular}{|c|c|c|}
\hline \multicolumn{3}{|c|}{$\begin{array}{l}\text { Sosial Politik Humaniora } \\
\text { http://journal.umpo.ac.id/index.php/aristo / aristo@umpo.ac.id }\end{array}$} \\
\hline \multirow{9}{*}{$\begin{array}{l}\text { STRUKTUR } \\
\quad \text { SKRIP }\end{array}$} & & $\begin{array}{l}\text { khusus Malang. Tapi hanya objeknya mono-ton, setelah program ini, } \\
\text { paket promo wisata akan ditam-bah lagi. "Banyak sekali wisata yang } \\
\text { harus diketahui. "kalua di Yogja kana da andong Malang sebaiknya } \\
\text { juga begitu. Budayanya lebih dikentalkan lagi," } \\
\text { Bupati Malang Rendra Kresna } \\
\text { "Kabupaten Malang memang ingin lebih menjual potensi wisata } \\
\text { lebih jauh lagi. Akhirnya program ini dapat terlaksana di sini," } \\
\text { Pemilihan narasumber dan pernyataan oleh wartawan diatas } \\
\text { dikonstruksikan sedemikian rupa sehingga memper-kuat argumen } \\
\text { tentang langkah yang dilakukan oleh Rendra Kresna, tanpa adanya } \\
\text { pernyataan yang memberikan masukan tentang apa yang seharusnya } \\
\text { dilakukan agara potensi wisata di kabupaten malang lebih baik lagi }\end{array}$ \\
\hline & $\begin{array}{l}\text { Pernyataan/ opini } \\
\text { penulis }\end{array}$ & $\begin{array}{l}\text { Paling tidak, program ini mampu membuat objek wisata Kabupaten } \\
\text { Malang semakin dikenal. Praktis, meningkat-kan wisatawan asing } \\
\text { maupun lokal. Setidaknya, wisatawan terdongkrak } 20 \text { persen dari } \\
\text { total target nasional menarik } 20 \text { juta wisatawan mancanegara. }\end{array}$ \\
\hline & Penutup & $\begin{array}{l}\text { Lebih lanjut Hari menambahkan, ada catatan yang harus diketahui } \\
\text { pemerintah daerah untuk memacu kunjungan wisata. Kalau di Yogja } \\
\text { kana da andong. Malang sebaiknya juga begitu. Budayanya lebih } \\
\text { dikentalkan lagi," imbuhnya }\end{array}$ \\
\hline & What & $\begin{array}{l}\text { Kabupaten Malang pamer kekayaan objek wisata alam dan sejarah } \\
\text { pada Ajang Jatim Travel Mart (JTM) V }\end{array}$ \\
\hline & Who & Bupati Malang Rendra Kresna \\
\hline & When & 6/10/2015. \\
\hline & Where & Pendopo Pemkab Malang \\
\hline & Why & $\begin{array}{l}\text { Paling tidak, program ini mampu membuat objek wisata Kabupaten } \\
\text { Malang semakin dikenal. Praktis, meningkat-kan wisatawan asing } \\
\text { maupun lokal. Setidaknya, wisatawan terdongkrak } 20 \text { persen dari } \\
\text { total target nasional menarik } 20 \text { juta wisatawan mancanegara. }\end{array}$ \\
\hline & How & $\begin{array}{l}\text { Ajang Jatim Travel Mart (JTM) V di Kabupaten Malang menjadi } \\
\text { momen emas pamer kekayaan objek wisata alam dan sejarah. Ada } 63 \\
\text { buyer dari berbagai daerah dan } 60 \text { seller dari kalangan pelaku wisata } \\
\text { yang hadir. Kegiatan yang diprakarsai oleh Badan Promosi } \\
\text { Pariwisata Daerah Jatim (BPPD) Jatim Dwi Cahyono ini digelar } \\
\text { selama tiga hari, 6-8 Oktober. }\end{array}$ \\
\hline $\begin{array}{l}\text { Struktur } \\
\text { Tematik }\end{array}$ & $\begin{array}{l}\text { Paragraph, } \\
\text { proposisi, kalimat, } \\
\text { hubungan antar } \\
\text { kalimat }\end{array}$ & $\begin{array}{l}\text { Secara keseluruhan wartawan mengkontruksi berita bahwa program } \\
\text { untuk menjual objek wisata di kabupaten Malang sudah dilakukan } \\
\text { dan mendapatkan apresiasi yang baik dari berbagai pihak terkait. }\end{array}$ \\
\hline Struktur Retoris & $\begin{array}{l}\text { Kata, idiom, } \\
\text { gambar/foto, grafik }\end{array}$ & $\begin{array}{l}\text { Menggunakan kata seller dan buyer untuk mempertegas konteks } \\
\text { kalimat jualan objek wisata. } \\
\text { Pada gambar terlihat ketua BPPD Jatim Dwi cahyono menyerahkan } \\
\text { cindera mata ke Bupati Malang Rendra Kresna di Pendapa } \\
\text { Kabupaten Malang }\end{array}$ \\
\hline
\end{tabular}

\section{Berita 7 oktober 2015}

Rahadi. Pembingkaian Berita Pada Media Lokal / 03/ Vol.5. No. 1. Tahun 2017 

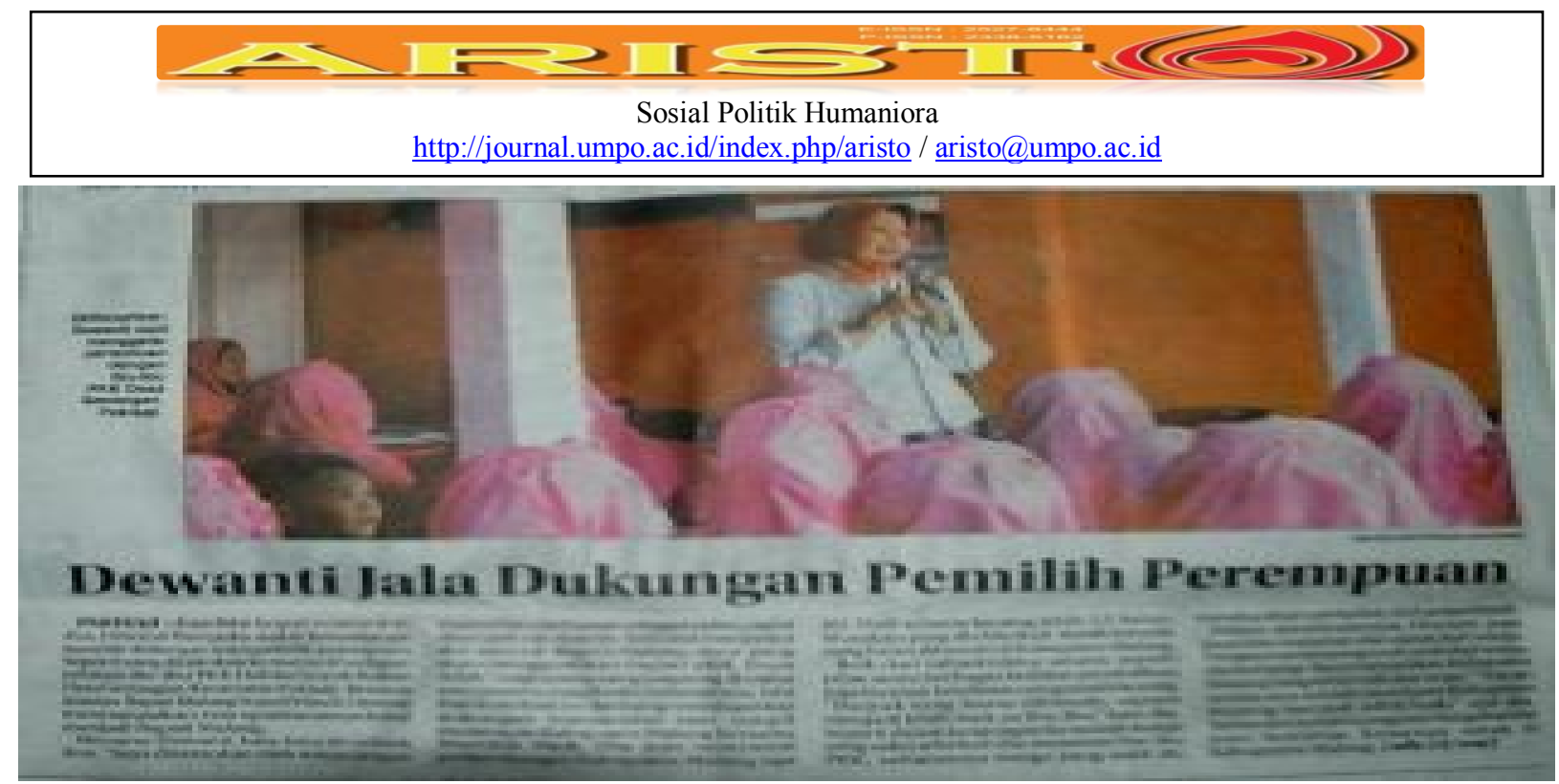

\section{Judul Berita: Dewanti Jala Dukungan Pemilih Perempuan \\ Isi Berita:}

Pakisaji- Kandidat bupati nomor urut dua, Dewanti Rumpoko makin bersemangat menyisir dukungan suara pemilih perempuan. Seperti yang dilakukan kemarin di hadapan ratusan ibu-ibu PKK Dahlia Guyub Rukun Desa Genangan, Kecamatan Pakisaji. Bersama mantan bupati Malang Sujud Pribadi, Dewanti menyampaikan rasa optimismenya bakal menjadi Bupati Malang. Menurut dewanti, kata-kata itu sudah doa. "saya disarankan oleh warga jangan menyebut diri sebagai calon terus. Jadi saya menyebut diri saya ini bupati Malang Anyar yang akan menggantikan bupati aktif, insyaallah, ungkapnya yang langsung diamini para peserta yang hadir. Selanjutnya istri walikota batu ini berharap mendapakan dukungan masyarakat saat tampil memimpin kabupaten Malang bersama masrifah hadi. Dia pun menyoroti perkembangan Kabupaten Malang saat ini. Dari selama kurang lebih 2,5 bulan blusukan yang dia lakukan, masih banyak yang harus dibenahi di Kabupaten Malang. Baik dari infrastruktur umum, seperti jalan serta berbagai fasilitas pendidikan juga layanan kesehatan yang masih kurang. "Banyak yang harus dibenahi, supaya menjadi lebih baik ya ibu-ibu" kata dia. Seperti kunjungan kerumah warga yang sakit sebelum dia menemui ibu-ibu PKK, seharusnya warga yang sakit itu mendapatkan perhatian dari pemerintah. Dalam pertemuannya dewanti juga meminta masukan dan saran dari warga. Dengan menampung unek-unek dari wargadia berharap dapat menjadikan kabupaten malang menjadi lebih baik dan maju, "tujuan utama saya adalah membawa kabupaten malang menjadi lebih baik” ujar dia. Tentunya melalui program Sanghanyar atau Sembilan kebaruan untuk di Kabupaten Malang (adk/c2/nay)

Tabel 8

Analisis Framing Pan Dan Kosicki Berita Diatas

\begin{tabular}{|c|c|c|}
\hline $\begin{array}{l}\text { Perangkat } \\
\text { Framing }\end{array}$ & Unit pengamatan & Hasil pengamatan \\
\hline \multirow{4}{*}{$\begin{array}{l}\text { STRUKTUR } \\
\text { SINTAKSIS }\end{array}$} & Judul & Dewanti Jala Dukungan Pemilih Perempuan \\
\hline & Lead & $\begin{array}{l}\text { Kandidat bupati nomor urut dua, Dewanti Rumpoko makin } \\
\text { bersemangat menyisir dukungan suara pemilih perempuan }\end{array}$ \\
\hline & Latar informasi & $\begin{array}{l}\text { Dari selama kurang lebih } 2,5 \text { bulan blusukan yang dia lakukan, masih } \\
\text { banyak yang harus dibenahi di Kabupaten Malang. Baik dari } \\
\text { infrastruktur umum, seperti jalan serta berbagai fasilitas pendidikan } \\
\text { juga layanan kesehatan yang masih kurang }\end{array}$ \\
\hline & Kutipan sumber & $\begin{array}{l}\text { DewantiRumpoko } \\
\text { banyak yang harus dibenahi supaya menjadi lebih baik ya ibu-ibu. } \\
\text { tujuan utama saya adalah membawa kabupaten malang menjadi lebih } \\
\text { baik" } \\
\text { Terlihat bahwa kutipan yang dituliskan wartawan adalah saat Dewanti }\end{array}$ \\
\hline
\end{tabular}

Rahadi. Pembingkaian Berita Pada Media Lokal / 03/ Vol.5. No. 1. Tahun 2017 


\begin{tabular}{|c|c|c|}
\hline \multicolumn{3}{|c|}{ 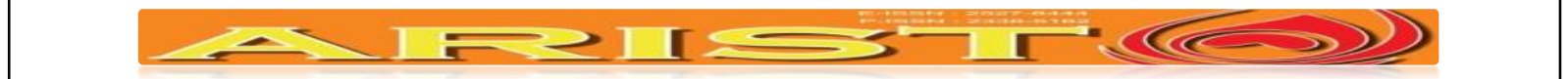 } \\
\hline & & Rumpoko sedang berbincang-bincang dengan ibu-ibu peserta acara. \\
\hline & $\begin{array}{l}\text { Pernyataan/opini } \\
\text { penulis }\end{array}$ & \\
\hline & Penutup & $\begin{array}{l}\text { Tentunya melalui program Sanghanyar atau Sembilan kebaruan untuk } \\
\text { di Kabupaten Malang }\end{array}$ \\
\hline \multirow{6}{*}{$\begin{array}{l}\text { STRUKTUR } \\
\text { SKRIP }\end{array}$} & What & $\begin{array}{l}\text { Kandidat bupati nomor urut dua, Dewanti Rumpoko makin } \\
\text { bersemangat menyisir dukungan suara pemilih perempuan. Seperti } \\
\text { yang dilakukan kemarin di hadapan ratusan ibu-ibu PKK Dahlia } \\
\text { Guyub Rukun Desa Genangan, Kecamatan Pakisaji }\end{array}$ \\
\hline & Who & Kandidat bupati nomor urut dua, Dewanti Rumpoko \\
\hline & When & $6 / 10 / 2015$ \\
\hline & Where & Desa Genangan, Kecamatan Pakisaji \\
\hline & Why & $\begin{array}{l}\text { Dari selama kurang lebih } 2,5 \text { bulan blusukan yang dia lakukan, masih } \\
\text { banyak yang harus dibenahi di Kabupaten Malang. Baik dari } \\
\text { infrastruktur umum, seperti jalan serta berbagai fasilitas pendidikan } \\
\text { juga layanan kesehatan yang masih kurang }\end{array}$ \\
\hline & How & $\begin{array}{l}\text { Melalui program Sanghanyar atau Sembilan kebaruan untuk di } \\
\text { Kabupaten Malang }\end{array}$ \\
\hline $\begin{array}{l}\text { Struktur } \\
\text { Tematik }\end{array}$ & $\begin{array}{l}\text { Paragraf, proposisi, } \\
\text { kalimat, hubungan } \\
\text { antar kalimat }\end{array}$ & $\begin{array}{l}\text { Terdapat } 5 \text { paragraf dalam berita ini. Struktur berita dibuat dengan } \\
\text { optimism dewanti akan memenangkan pemilu kabupaten Malang, } \\
\text { karena mendapatkan dukungan suara dari ibu-ibu. Yang menarik } \\
\text { adalah saat wartawan menulis kalimat Bersama mantan bupati } \\
\text { Malang, Sujud Pribadi seolah ingin ditegaskan bahwa Dewanti } \\
\text { Didukung oleh Mantan Bupati Malang yang juga berasal dari PDIP } \\
\text { (namun tidak diberikan porsi berita tersendiri tentang alasannya } \\
\text { mendukung dan apa yang akan dilakukan sebagai salah satu orang } \\
\text { yang akan mengantarkan Dewanti Rumpoko untuk menang). Ini } \\
\text { berbeda dengan yang ada pada berita yang lain (Radar Malang tanggal } \\
2 \text { Oktober 2015), juga diberita tentang slah satu petinggi di PDIP } \\
\text { (Geng Wahyudi) malah mendukung calon lain. }\end{array}$ \\
\hline $\begin{array}{l}\text { Struktur } \\
\text { Retoris }\end{array}$ & $\begin{array}{l}\text { Kata, idiom, } \\
\text { gambar/foto, grafik }\end{array}$ & $\begin{array}{l}\text { Banyak menggunakan kata dibenahi, yang menegaskan bahwa di } \\
\text { kabupaten Malang masih banyak kekurangan } \\
\text { Pada foto terlihat dewanti saat menggelar pertemuan dengan ibu-ibu } \\
\text { PKK Desa Genangan Pakisaji yang saat itu menggunakan pakaian } \\
\text { dengan warna serba pink yang menegaskan unsure feminim }\end{array}$ \\
\hline
\end{tabular}

\section{Berita 7 Oktober 2015}

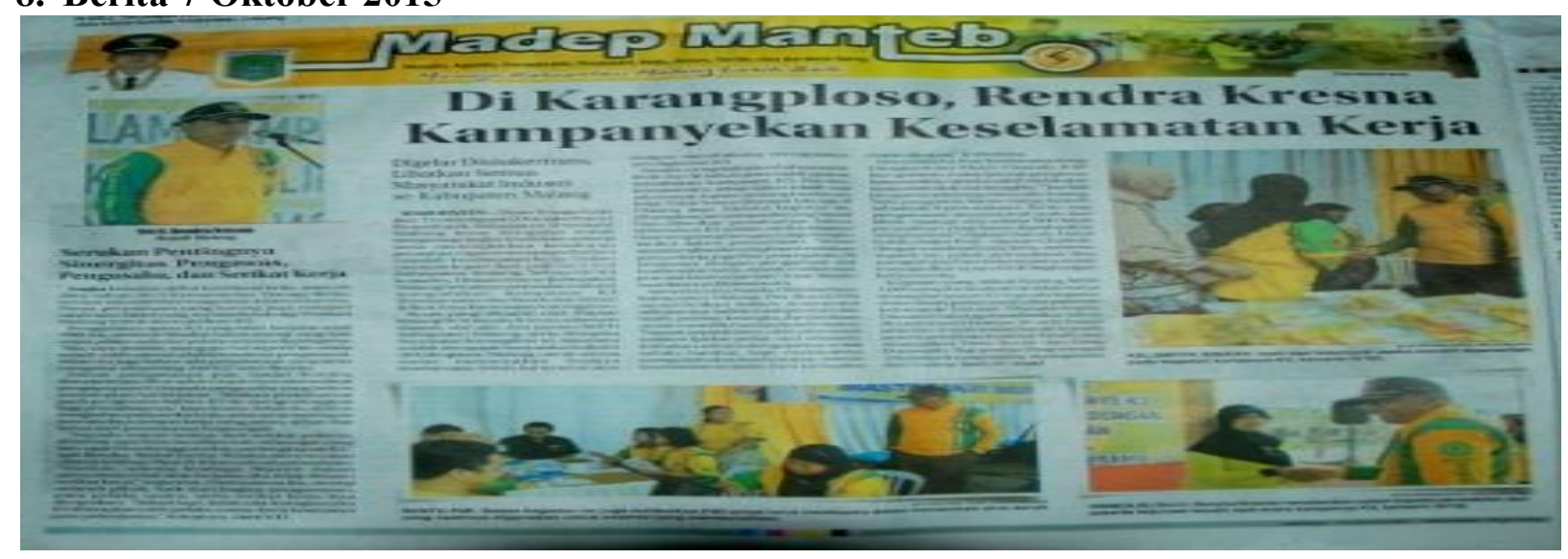

Judul berita: Di Karangploso, Rendra Kresna Kampanyekan Keselamatan Kerja 


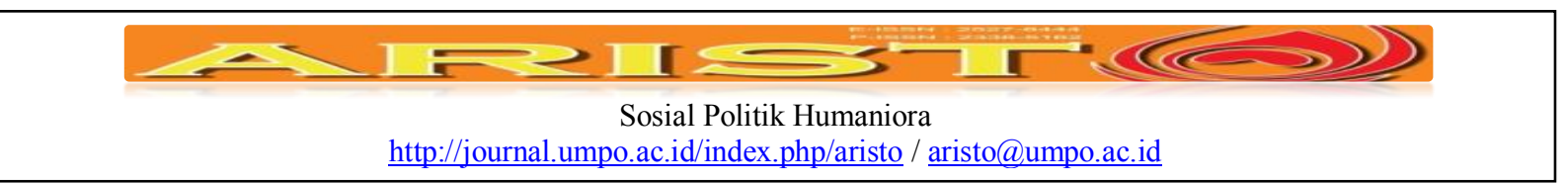

\section{Isi Berita:}

\section{*Digelar disnakertrans, Libatkan Semua Masyarakat Industri se-Kabupaten Malang}

KABUPATEN- Dinas tenaga kerja dan transmigrasi (disnakertrans) Pemerintah kabupaten (Pemkab) Malang terus berupaya untuk mengurangi tingkat kecelakaan pekerja serta meningkatkan kesadaran perusahaan agar terus memperhatikan masalah keselamatan kerja. Dalam memperingati hari jadi ke 1.255 kabupaten malang, selasa (6/10) kemarin, disnakertrans kabupaten malang bersama masyarakat industry mengadakan kampanye K3 (Keselamatan dan Kesehatan Kerja)di rest area kecamatan karangploso. Acara yang dihari oleh bupati Malang Dr Rendra Kresna, Sekertaris daerah, staff ahli dan jajaran SKPD Kabupaten Malang, serta Muspika kecamatan Karangploso ini, tujuannya adalah mengajak masyarakat industry di Kabupaten Malang untuk secara sadar menerapkan budaya keselamatan. Sebab hal tersebut akan sangat mendukung tercapainya peningkatan $k 3$. Rendra mengungkapkan bahwa sudah lebih dari 30 tahun pemerintah gencar melakukan kampanye K3. Namun kenyataannya, setiap tahun masih saja ada temuan laporan tentang kecelakaan kerja. Tidak hanya ditempat lain, tetapi di Malang juga. Melalui kegitan ini diharapkan para pengusaha yang bandel bisa diberikan pemahaman bahwa keberadaan $K 3$ adalah untuk mengatasi dan mengurangi kerugian yang mungkin timbul dalam perusahaan. "selain meminimalisasi kemungkinan kecelakaan para pekerja, juga bisa pencegahan. Diantaranya dengan pengadaan alat keselamatan kerja, seperti masker ataupun alat keamanan lain" tutur rendra saat ditemui di lokasi acara. Sementra itu, kepala Disnakertrans Kabupaten Malang Drs Razali M.Si menyebutkan bahwa masyarakat sebenarnya sudah memiliki nilai, benih, potensi, kerangka, dan landasan untuk memiliki budaya keselamatan. Seperti pepatah jawa, alon-alon waton kelakon (pelan-pelan asal selamat). Ini bukan artinya mengajarkan untuk seslalu terlambat, tapi maksudnya mengutamakan keselamatan. Setelah keselamatan terjamin, barulah kualitas dapat dicapai" imbuhnya. Sementara itu, Kasi Keselamatan kerja disnakertrans Moch Chairuly R SP mengatakan walau jumlah pengawas hanya sedikit, mereka sudah melakukan upaya semaksimal mungkin. Jumlah pengawas sekarang cuma 3 orang. Satu pengawas meng handle sebanyak 8 perusahaan. Tentu saja pengawasan menyeluruh jauh lebih ideal. Apalagi ada lebig dari 900 perusahaan yang harus diperhatikan setiap harinya," Ungkap Chairuly. Untuk itulah, lanjut ruly-sapaan Chairuly dengan sosialisasi yang terus menerus seperti ini, pihak perusahaan bisa mengerti dan bisa bekerja sama untuk mewujudkan upaya K3 di lingkungan kerja mereka. Kegiatan yang diikuti kurang lebih 1.000 orang dari industry ini tidak hanya kampanye tentang kampanye K3. Juga ada kegiatan donor darah, pasar murah dan pameran kelompok binaan Disnakertrans. Disnakertrans juga memberikan hibah 20 unit mesin berupa 10 unit mesin jahit dan 10 unit mesin bordirkepada peserta latihan kejuruhan border dari masyarakat Desa Bocek dan desa Donowarih. Tiap peserta dibagi menjadi 10 kelompok yang masing-masing terdiri dari 3 orang. (oct/c1/mas)

\section{Tabel 9}

Analisis Framing Pan Dan Kosicki Berita Diatas

\begin{tabular}{|c|l|l|}
\hline $\begin{array}{c}\text { Perangkat } \\
\text { Framing }\end{array}$ & \multicolumn{1}{|c|}{$\begin{array}{c}\text { Unit } \\
\text { pengamatan }\end{array}$} & \multicolumn{1}{c|}{ Hasil pengamatan } \\
\hline \multirow{3}{*}{$\begin{array}{c}\text { STRUKTUR } \\
\text { SINTAKSIS }\end{array}$} & Judul & Di Karangploso, Rendra Kresna Kampanyekan Keselamatan Kerja \\
\cline { 2 - 3 } & Lead & $\begin{array}{l}\text { Dinas tenaga kerja dan transmigrasi (disnakertrans) Pemerintah } \\
\text { kabupaten (Pemkab) Malang terus berupaya untuk mengurangi tingkat } \\
\text { kecelakaan pekerja serta meningkatkan kesadaran perusahaan agar } \\
\text { terus memperhatikan masalah keselamatan kerja. }\end{array}$ \\
\cline { 2 - 3 } & Latar informasi & $\begin{array}{l}\text { Setiap tahun masih saja ada temuan laporan tentang kecelakaan kerja. } \\
\text { Tidak hanya ditempat lain, tetapi di Malang juga }\end{array}$ \\
\cline { 2 - 3 } & Kutipan sumber & $\begin{array}{l}\text { Rendra Kresna } \\
\text { Selain meminimalisasi kemungkinan kecelakan para pekerja, juga } \\
\text { bisa pencegahan. Diantaranya dengan pengadaan alat keselamatan } \\
\text { kerja, seperti masker ataupun alat keamanan lain" }\end{array}$ \\
\hline
\end{tabular}

Rahadi. Pembingkaian Berita Pada Media Lokal / 03/ Vol.5. No. 1. Tahun 2017 


\begin{tabular}{|c|c|c|}
\hline \multicolumn{3}{|c|}{ 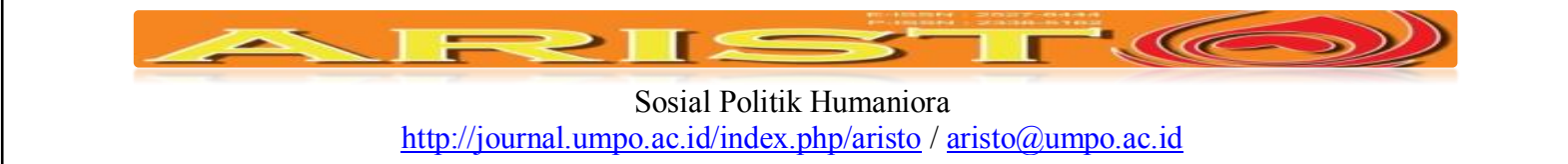 } \\
\hline & & $\begin{array}{l}\text { Drs Razali M.Si } \\
\text { "Seperti pepatah Jawa, Alon- alon waton kelakon (pelan-pelan asal } \\
\text { selamat). Ini bukan artinya mengajarkan untuk seslalu terlambat, tapi } \\
\text { maksudnya mengutamakan keselamatan. Setelah keselamatan } \\
\text { terjamin, barulah kualitas dapat dicapai" } \\
\text { Kasi Keselamatan kerja disnakertrans Moch Chairuly R SP } \\
\text { "Jumlah pengawas sekarang Cuma } 3 \text { orang. Satu pengawas meng } \\
\text { handle sebanyak } 8 \text { perusahaan. Tentu saja pengawasan menyeluruh } \\
\text { jauh lebih ideal. Apalagi ada lebig dari } 900 \text { perusahaan yang harus } \\
\text { diperhatikan setiap harinya," }\end{array}$ \\
\hline & $\begin{array}{l}\text { Pernyataan/opini } \\
\text { penulis }\end{array}$ & \\
\hline & Penutup & $\begin{array}{l}\text { Disnakertrans juga memberikan hibah } 20 \text { unit mesin berupa } 10 \text { unit } \\
\text { mesin jahit dan } 10 \text { unit mesin bordir kepada peserta latihan kejuruhan } \\
\text { border dari masya-rakat Desa Bocek dan desa Donowarih. Tiap } \\
\text { peserta dibagi menjadi } 10 \text { kelompok yang masing-masing terdiri dari } \\
3 \text { orang. }\end{array}$ \\
\hline \multirow{6}{*}{$\begin{array}{l}\text { STRUKTUR } \\
\text { SKRIP }\end{array}$} & What & $\begin{array}{l}\text { Dalam memperingati hari jadi ke } 1.255 \text { kabupaten malang, } \\
\text { disnakertrans kabupaten malang bersama masyarakat industry } \\
\text { mengadakan kampanye K3 (Keselamatan dan Kesehatan Kerja)di rest } \\
\text { area kecamatan karangploso }\end{array}$ \\
\hline & Who & Kandidat bupati nomor urut dua, Dewanti Rumpoko \\
\hline & When & $6 / 10 / 2015$ \\
\hline & Where & Rest Area kecamatan Karangploso \\
\hline & Why & $\begin{array}{l}\text { Mengurangi tingkat kecelakaan pekerja serta meningkatkan kesadaran } \\
\text { perusahaan agar terus memperhatikan masalah keselamatan kerja. }\end{array}$ \\
\hline & How & $\begin{array}{l}\text { Sudah lebih dari } 30 \text { tahun pemerintah gencar melakukan kampanye } \\
\text { K3. }\end{array}$ \\
\hline $\begin{array}{l}\text { Struktur } \\
\text { Tematik }\end{array}$ & $\begin{array}{l}\text { Paragraf, proposisi, } \\
\text { kalimat, hubungan } \\
\text { antar kalimat }\end{array}$ & $\begin{array}{l}\text { Terdapat } 6 \text { paragraf dalam berita ini. Struktur berita dibuat dengan } \\
\text { diawali pada paragraph awal tentang adanya kampanye K3 yang } \\
\text { diadakan oleh disnaker-trans kabupaten Malang. Pada paragraf } \\
\text { selanjutnya dikonstruksi oleh wartawan dengan menekankan program } \\
\text { acara ini bagi masyarakat industry terutama untuk keselamatan } \\
\text { mereka dan ini dikuatkan dengan pernyataan Rendra kresna selaku } \\
\text { Bupati Malang begitu juga kepala disnakertrans dan kepala seksi } \\
\text { keselamatan kerja disnakertrans. }\end{array}$ \\
\hline $\begin{array}{l}\text { Struktur } \\
\text { Retoris }\end{array}$ & $\begin{array}{l}\text { Kata, idiom, } \\
\text { gambar/foto, grafik }\end{array}$ & $\begin{array}{l}\text { Penggunakan idiom jawa Alon-alon waton kelakon (pelan-pelan asal } \\
\text { selamat sebagai penguat bahwa sesungguhnya masyarakat sudah } \\
\text { memahi konsep keselamatan dalam bekerja. } \\
\text { Pada foto nampak Rendra Kresna memberikan salam kepada } \\
\text { perwakilan dari peserta kejuruan border yang saat itu menggunkan } \\
\text { pakaian yang serupa warnanya dengan rendra kresna yaitu warna } \\
\text { kuning dan hijau. Perlu diingat bahwa rendra kresna adalah kader dari } \\
\text { partai Golkar. }\end{array}$ \\
\hline
\end{tabular}

\section{Berita 7 Oktober 2015}

Rahadi. Pembingkaian Berita Pada Media Lokal / 03/ Vol.5. No. 1. Tahun 2017 


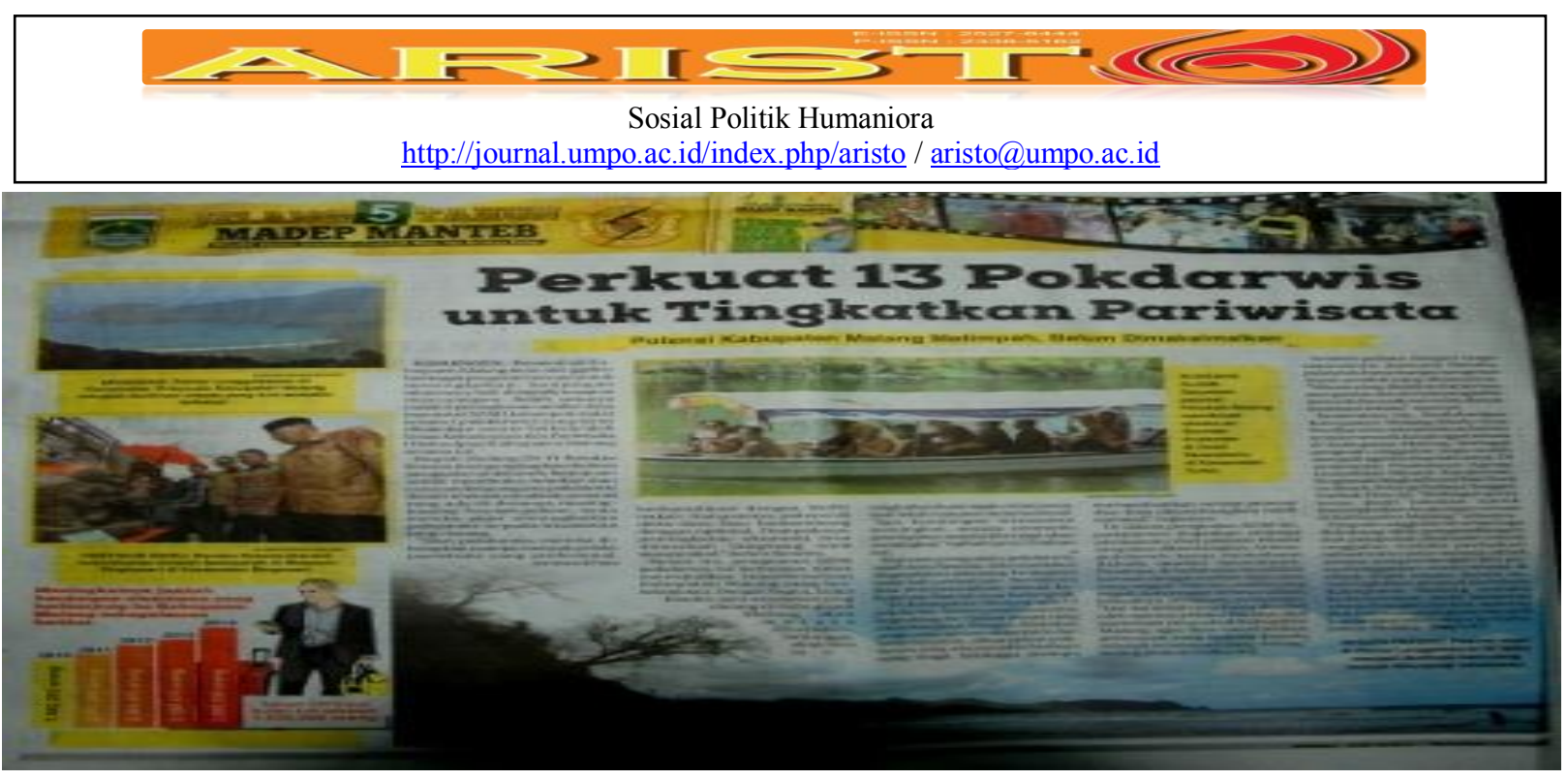

\section{Judul Berita : Perkuat 13 Pokdarwis Untuk Tingkatkan Pariwisata}

Isi berita:

Kabupaten - pemerintah kabupaten malang terus menggeber berbagai program inovasi untuk meningkatkan kunjungan wisatawan, baik domestic maupun mancanegara. Salah satunya melalui peningkatan sumber daya manusia (SDM) kelompok sadar wisata (Pokdarwis) yang terus dilakukan secara berkala oleh Dinas Kebudayaan dan pariwisata (Disbudpar) Kabupaten Malang selama ini Bupati Malang Dr H Rendra Kresna mengungkapkan bahwa penguatan pokdarwis bertujuan untuk membuka mindset dan cara pandang anggota pokdarwis dalam memaksimalkan potensi yang ada di desanya masing-masing. Setelah paham tentu mereka akan meningkatkan pelayanan kepada wisatawan yang datang. Dari pokdarwis mereka diharapkan mampu menjadi pelaku pariwisata yang professional termasuk bisa berkoordinasi dengan SKPD terkait. Harapannya, potensi di desa-desa bisa berkembang dengan optimal. Dampaknya, peningkatan ekonomi bisa dirasakan langsung oleh masyarakat," beber Rendra. Selain itu penguatan SDM pokdarwis bertujuan untuk mewujudkan kepariwisataan Kabupaten Malang yang berkelanjutan. Dengan begitu lanjut rendra, para wisatawan yang dating di Kabupaten Malang akan merasa dirajakan. Sehingga akan meningkatkan kunjungan wisata baik local maupun internasional. Jika kunjungan wisatawan meningkat secara otomatis pendapatan masyarakat juga akan meningkat' imbuh pria 53 tahun ini. Kegiatan penguatan pokdarwis, masih kata rendra dalam setahun diagendakan sekurang-kurangnya enam kali pertemuan. Bentuknya menyesuaikan kebutuhan daerah atau kelompok. "dikabupaten Malang ada 13 pokdarwis. System pembinaannya tergantung dari lokasi wisata yang dikembangkan. Dengan dilakukan penguatan secara sistematis dan berkelanjutan, diharapkan pokdarwis yang ada semakin berdaya saing tinggi. Sehingga mampu memanfaatkan setiap potensi dan bisa dikembangkan lebih optimal' tegasnya. Di dalam penguatan SDM ini, Pokdarwis diajarkan strategi pemasaran dari potensi wisata yang akan dikembangkan. Artinya pokdarwis harus memahami dahulu market sasarannya. Pasalnya, di Indonesia ini adalah kawasan dengan sumber Alam yang unggul. Namun realita yang terjadi kekurangan terbesar adalah lemahnya dibidang pelayanan. Hal ini harus disadari oleh semua pelaku budaya dan pariwisata yang ada di kabupaten Malang agar bisa memberikan pelayanan optimal kepada seluruh wisatawan yang datang” terang politisi Golkar ini. Setelah paham dengan target sasarannya, menurut rendra pokdarwis harus mampu mengemas suatu produk yang ditawarkan. Wisata yang disajikan harus bisa mengemas sisi sisi lain yang lebih menarik dan unik dari suatu daerah destinasi wisata" ujarnya, Sementara itu, kadisbudpar kabupaten Malang Made Arya Wedhantara menuturkan bahwa untuk menarik kunjungan wisata di Kabupaten Malang, berbagai program sudah menjadi agenda setiap tahunnya. Diantaranya Pisowanan Agung, Gemebyar Bhumi Kanjuruan, Singhasari Magnificient fair, rock on beach, pelangi budaya tengger, gerebek tirto aji. "Berbagai upaya terus kami lakukan untuk meningkatkan kunjungan wisa di Kabupaten Malang,jelasnya. Program unggulan tersebut juga didukung oleh pengembangan dan penguatan 


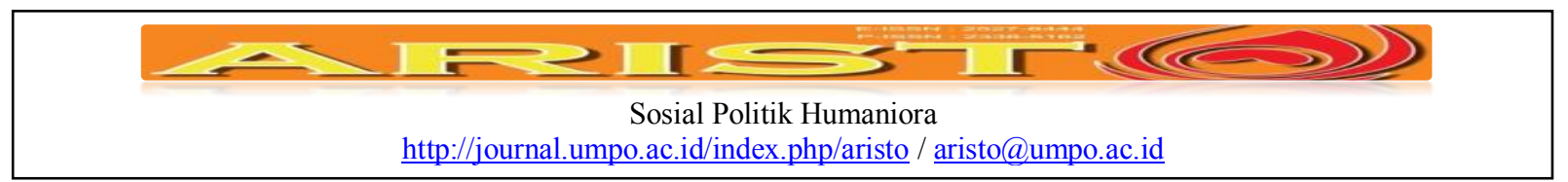

destinasi wisata unggulan melalui perbaikan infrastruktur jalan menuju obyek wisata-obyek wisata. Selain itu meningkatkan promosi pariwisata Kabupaten Malang melalui keikutsertaan pada pameran wisata di tingkat provinsi, nasional dan internasional guna menarik kunjungan wisatawan ke Kabupaten Malang. (Fay/c1)

\section{Tabel 10}

Analisis Framing Pan Dan Kosicki Berita Diatas

\begin{tabular}{|c|c|c|}
\hline $\begin{array}{l}\text { Perangkat } \\
\text { Framing }\end{array}$ & Unit pengamatan & Hasil pengamatan \\
\hline \multirow{6}{*}{$\begin{array}{l}\text { STRUKTUR } \\
\text { SINTAKSIS }\end{array}$} & Judul & Perkuat 13 Pokdarwis Untuk Tingkatkan Pariwisata \\
\hline & Lead & $\begin{array}{l}\text { Pemerintah kabupaten malang terus menggeber berbagai program } \\
\text { inovasi untuk meningkatkan kunjungan wisatawan, baik domestic } \\
\text { maupun mancanegara }\end{array}$ \\
\hline & Latar informasi & $\begin{array}{l}\text { Membuka mindset dan cara pandang anggota pokdarwis dalam } \\
\text { memaksimalkan potensi yang ada di desanya masing-masing }\end{array}$ \\
\hline & Kutipan sumber & $\begin{array}{l}\text { Rendra Kresna } \\
\text { "Dari pokdarwis mereka diharapkan mampu menjadi pelaku } \\
\text { pariwisata yang professional termasuk bisa berkoordinasi dengan } \\
\text { SKPD terkait. Harapannya, potensi di desa-desa bisa berkembang } \\
\text { dengan optimal. Dampaknya, peningkatan ekonomi bisa dirasakan } \\
\text { langsung oleh masyarakat," } \\
\text { "Jika kunjungan wisatawan meningkat secara otomatis pendapatan } \\
\text { masyarakat juga akan meningkat' } \\
\text { "Di kabupaten Malang ada } 13 \text { pokdarwis. System pembi-naannya } \\
\text { tergantung dari lokasi wisata yang dikembangkan. Dengan dilakukan } \\
\text { penguatan secara sistematis dan berkelanjutan, diharapkan pokdarwis } \\
\text { yang ada semakin berdaya saing tinggi. Sehingga mampu } \\
\text { memanfaatkan setiap potensi dan bisa dikembangkan lebih optimal" } \\
\text { "hal-hal inilah yang harus disadari oleh semua pelaku budaya dan } \\
\text { pariwisata yang ada di kabupaten Malang agar bisa memberikan } \\
\text { pelayanan optimal kepada seluruh wisatawan yang dating" } \\
\text { "wisata yang disajikan harus bisa mengemas sisi-sisi yang lain yang } \\
\text { lebih menarik dan unik dari suatu daerah destinasi wisata" } \\
\text { Made Arya Wedhantara (Kadisbudpar kabupaten Malang) } \\
\text { Berbagai upaya terus kami lakukan untuk meningkatkan kunjungan } \\
\text { wisata di Kabupaten Malang" } \\
\text { Dapat dilihat bahwa sebagian besar kondtruksi pemberi-taan ini } \\
\text { didominasi oleh kutipan-kutipan dari Rendra Kresna saja. Sehingga } \\
\text { berita ini mirip dengan pers list yang biasanya dibagikan kepada } \\
\text { wartawan oleh panitia. Hanya kutipan dari Kadisbudpar saya yang } \\
\text { digunakan dalam rangka untuk memperkuat pernyataan dari Rendra } \\
\text { Kresna. }\end{array}$ \\
\hline & $\begin{array}{l}\text { Pernyataan/opini } \\
\text { penulis }\end{array}$ & \\
\hline & Penutup & $\begin{array}{l}\text { Selain itu meningkatkan promosi pariwisata Kabupaten Malang } \\
\text { melalui keikutsertaan pada pameran wisata di tingkat provinsi, } \\
\text { nasional dan internasional guna menarik kunjungan wisatawan ke } \\
\text { Kabupaten Malang }\end{array}$ \\
\hline $\begin{array}{l}\text { STRUKTUR } \\
\text { SKRIP }\end{array}$ & What & $\begin{array}{l}\text { Pemerintah kabupaten malang terus menggeber berbagai program } \\
\text { inovasi untuk meningkatkan kunjungan wisata-wan, baik domestic } \\
\text { maupun mancanegara. Salah satunya melalui peningkatan sumber } \\
\text { daya manusia (SDM) kelom-pok sadar wisata (Pokdarwis) yang terus } \\
\text { dilakukan secara berkala oleh Dinas Kebudayaan dan pariwisata } \\
\text { (Disbudpar) Kabupaten Malang selama ini }\end{array}$ \\
\hline
\end{tabular}

Rahadi. Pembingkaian Berita Pada Media Lokal / 03/ Vol.5. No. 1. Tahun 2017 


\begin{tabular}{|c|c|c|}
\hline \multicolumn{3}{|c|}{ 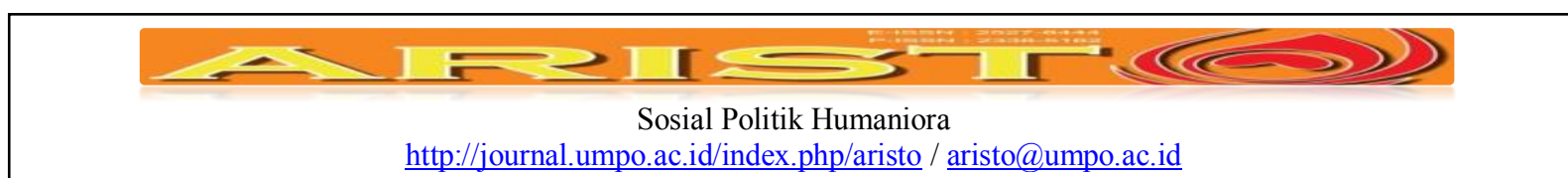 } \\
\hline & Who & Kelompok sadar wisata (Pokdarwis \\
\hline & When & \\
\hline & Where & \\
\hline & Why & $\begin{array}{llll}\begin{array}{l}\text { Untuk mewujudkan } \\
\text { berkelanjutan. }\end{array} & \text { kepariwisataan } & \text { Kabupaten } & \text { Malang yang } \\
\end{array}$ \\
\hline & How & $\begin{array}{l}\text { Meningkatkan promosi pariwisata Kabupaten Malang melalui } \\
\text { keikutsertaan pada pameran wisata di tingkat provinsi, nasional dan } \\
\text { internasional }\end{array}$ \\
\hline $\begin{array}{l}\text { Struktur } \\
\text { Tematik }\end{array}$ & $\begin{array}{l}\text { Paragraf, proposisi, } \\
\text { kalimat, hubungan } \\
\text { antar kalimat }\end{array}$ & $\begin{array}{l}\text { Terdapat } 10 \text { paragraf dalam berita dan didominasi oleh kutipan } \\
\text { peryataan dari Rendra Kresna, sehingga berita ini seperti pers list. }\end{array}$ \\
\hline $\begin{array}{l}\text { Struktur } \\
\text { Retoris }\end{array}$ & $\begin{array}{l}\text { Kata, idiom, } \\
\text { gambar/foto, grafik }\end{array}$ & $\begin{array}{l}\text { Penggunakan idiom merubah mindset yang bertu-juan untuk merubah } \\
\text { cara pandang anggota pokdarwis. Tidak ada kesinambungan antara } \\
\text { foto yang ditampilkan dengan berita utama. Sehingga terlihat seperti } \\
\text { asal tempel saja. Pun begitu dengan data berupa grafik yang } \\
\text { ditampilkan mengenai data tentang peningkatan jumlah wisatawan } \\
\text { yang berkunjung ke kabupaten Malang mulai tahun } 2010 \text { sampai } \\
\text { dengan tahun } 2014 \text { tanpa disertakan data tersebut berasal dari mana } \\
\text { sumbernya. }\end{array}$ \\
\hline
\end{tabular}

Dalam penelitian ini peneliti telah menetapkan teori hirarki pengaruh isi media dari Pamela J Shoemaker dan Stephen D. Reese sebagai pisau analisis temuan data. Berikut hasil dari diskusi teori yang telah dilakukan oleh peneliti:

\section{Level Organisasi}

Pada level ini pemberitaan di Radar Malang dipengaruhi oleh orientasi profesi yang disosialisasikan kepada mereka (oleh kebijakan organisasi). Artinya mereka diharuskan melakukan untuk sebuah pemberitaan dalam membangun cerita (citra Rendra Kresna). Pada berita yang ditulis oleh wartawan Radar Malang tanggal 1-7 Oktober merupakan hasil liputan dari beberapa jurnalis yang pastinya mempunyai latar belakang dan karakter yang berbeda.Namun karakter dan sifat pemberitaan mempunyai kesamaan apabila memberitakan tentang sosok Rendra Kresna. Design layout Radar Malang mem-berikan guide ke pembaca dengan cara membuat space dihalaman pertama kolom pertama sebelah atas kiri dengan ukuran kolom $10 \mathrm{~cm}$ X $6,3 \mathrm{~cm}$ yang berisi judul berita dan halaman berita selengkapnya. Design dibuat dengan dominasi kuning dan hijau tersebut memang dengan sangat mudah diartikan. Rendra Kresna merupakan kader dari partai Golkaryang terkenal dengan ikon warna kuning, serta warna hijau yang merepresen-tasikan dari Partai Kebangkitan Bangsa (PKB).

Memang tidak bisa dipungkiri dalam struktur organisasi media massa terdapat hirarki posisi. Pada lini depan terdapat reporter (tulis/foto) yang bertugas untuk mencari serta menulis berita 


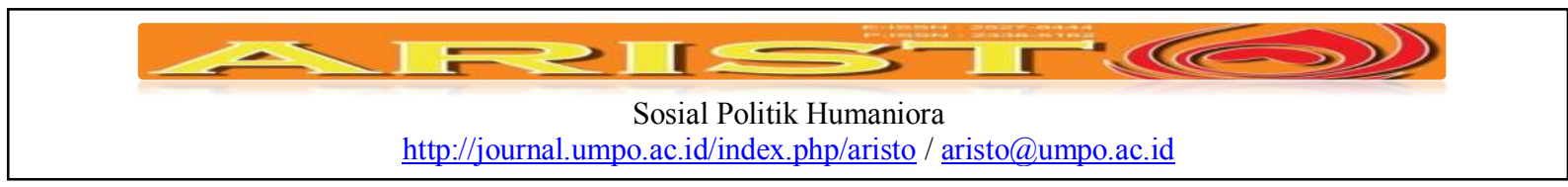

dari lapangan dan layouter. Selanjutnya ada editor/koordinator liputan yang bertugas mengkoordinasikan pembagian tugas kepada reporter serta melakukan editing naskah berita dari reporter (tulis/foto). Yang terakhir adalah direktur atau juga ada yang menggunakan istilah General Manager. Yang mempunyai tugas membuat kebijakan, mengambil keputusankeputusan penting terkait dengan kepentingan politik atau ekonomi media. Dengan adanya struktur seperti ini sering ideologi jurnalis penulis berita harus dikalahkan oleh kepentingan pemilik/ pengambil kebijakan.

2. Level Rutinitas Berita

Pamela J shoemaker dan Stephen D reese(1996:100)Mengatakan setiap orang tidak akan berfikir mengenai sesuatu tanpa adanya informasi atau pengaruh dari pemikiran orang lain. Ini dapat diartikan bahwa pemikiran orang merupakan kreasi dari yang lain. Bila dikaitkan dengan level rutinitas media maka tidak bisa dipungkiri jika sebuah pemberitaan yang sudah dikonstruksi sedemian rupa dengan durasi yang berulang-ulang maka akan membawa pengaruh (effect) yang besar kepada pembacanya. Radar Malang pada periode tanggal 1-7 Oktober memberitakan kegiatan dari Rendra Kresna selaku incumbent dengan space dan jumlah pemberitaan yang lebih banyak dibandingkan dengan calon pasangan yang lain. Hal ini terlihat sebanyak tujuh kali pemberitaan tentang Program dan kegiatan yang dilakukan oleh Rendra dalam kurun waktu tanggal 1-7 Oktober. Lebih menyoloknya, pada tanggal 7 Oktober Radar Malang memberikan dua kali ruang (dengan lebar setengah halaman) yang bila ditotal menjadi satu halaman full hanya untuk memberitakan tentang Rendra Kresna pada

Kolom yang diberi Judul Jelang 5 Tahun Madep Manteb. Sedangkan pasangan Dewanti rumpoko (pasangan calon no 2) hanya diberitakan satu kali dalam kurun waktu satu minggu, dan tidak ada pemberitaan samasekali untuk calon pasangan no 3 (yakni Nurcholis dan Muhammad Mufid dari jalur independen). Tentu saja dengan rutinitas media yang dilakukan oleh Radar nampaklah arah kebijakan dalam pemberitaan mereka.

\section{Kesimpulan}

Penelitian ini berfokus pada pembingkaian berita yang dilakukan oleh Radar Malang terkait dengan pemberitaan tentang calon Bupati dan Wakil Bupati Kabupaten Malang untuk periode 2015-2020. Radar Malang mengkonstruksi pemberitaan yang menurut peneliti kurang 


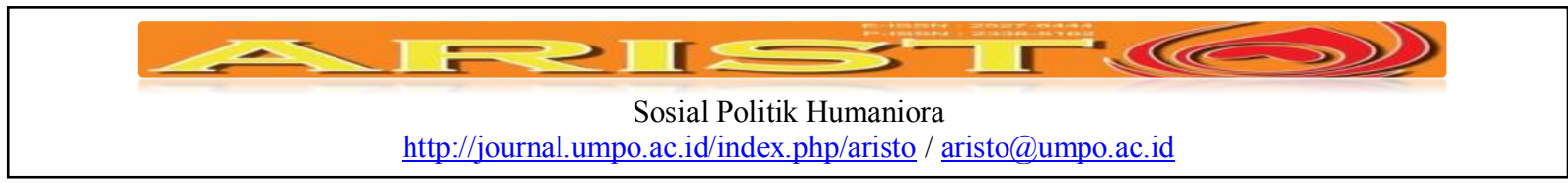

berimbang dalam jumlah maupun space (ruang) pada kolom Koran radar Malang. Adapun penjelasannya sebagai berikut:

1. Rendra Kresna selaku incumbent diberikan space dan jumlah pemberitaan yang lebih banyak dibandingkan dengan calon pasangan yang lain. Hal ini terlihat sebanyak tujuh kali pemberitaan tentang Program dan kegiatan yang dilakukan oleh Rendra dalam kurun waktu tanggal 1-7 Oktober. Dan yang lebih menyoloknya, pada tanggal 7 Oktober Radar Malang memberikan dua kali ruang (dengan lebar setengah halaman) yang bila ditotal menjadi satu halaman full hanya untuk memberitakan tentang Rendra Kresna pada Kolom yang diberi Judul Jelang 5 Tahun Madep Manteb

2. Pada halaman pertama Radar Malang selalui diberikan space untuk mengarahkan pembaca terkait dengan kolom Jelang 5 Tahun Madep Manteb beserta dengan judul berita yang diangkat.

3. Dewanti rumpoko (pasangan calon no 2) hanya diberitakan satu kali dalam kurun waktu satu minggu

4. Tidak ada pemberitaan sama sekali untuk calon pasangan no 3 (yakni Nurcholis dan Muhammad Mufid dari jalur independen)

5. Dikaitkan dengan teori Pengaruh isi media; dari faktor internal level yaitu level organisasi, dan level rutinitas media jelas bahwa Radar Malang sangat berpihak pada Rendra Kresna. Hal ini dikuatkan dengan pemberitaan yang cenderung bersifat positif dalam setiap berita yang ditampilkan. Bahkan ada berita yang isinya hamper sebagian besar hanya kutipan pernyataan dari Rendra Kresna saja. Sehingga tidak ubahnya seperti pers list saja.

Peneliti menyarakan kepada pemilik, pekerja media untuk lebih berimbang dalam menyampaikan berita terutama terkait dengan berita politik. Hal ini disebabkan dengan realitas politik di Indonesia saat ini yang sering menggunakan media massa sebagai alat untuk kampanye politik demi kepentingan beberapa orang saja. Memang tidak dapat dihindari bahwa media selalu bersentuhan dengan politik. Apalagi jika dilihat realitas media di Indonesia yang dimiliki oleh para petinggi partai politik. Namun terlepas dari itu, idealnya memang harus tetap cover bothside dalam setiap pemberitaannya.Sehingga peran dari media massa sebagai pilar keempat demokrasi dan lembaga yang memberikan keberimbangan dalam informasi tetap kokoh berdiri.Untuk akademisi, peneliti berharapkan untuk menggunakan model analisis framing yang lain, agar 


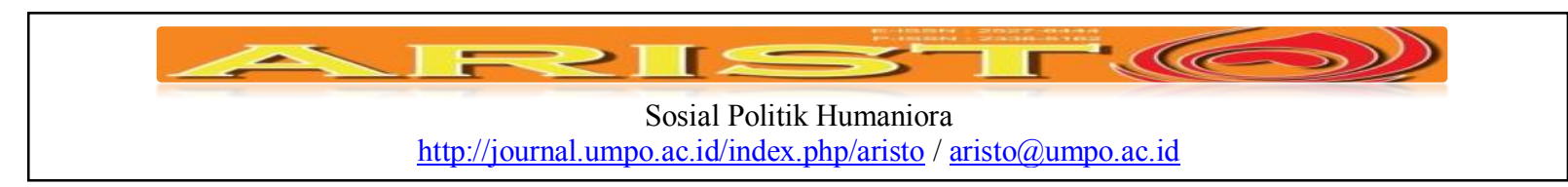

muncul banyak hasil penelitian, sehingga berdampak pada keanekaragaman dalam analisis framing. 


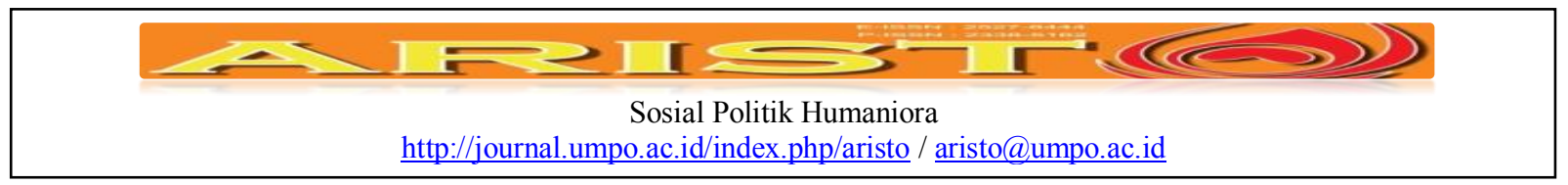

\section{Daftar Pustaka}

Ardiantoro, Fitra. 2010. Citra Pasangan Calon Walikota dan Wakil Walikota Bandar Lampung Periode 2010-2015 Dalam Pemberitaan Harian Umum Lampung Post (Studi Analsis Framing Menggunakan Model Zhongdang Pan dan Kosicki Edisi Juni 2010). Banten: Jurnal Riset Komunikasi Vol 1 No 2 (2010)

Bungin, Burhan. 2005. Metodelogi Penelitian Kualitatif. Cetakan Pertama. Jakarta: Prenada Media

Cangara, Hafied, 2009. Komunikasi Politik: Konsep, Teori, dan Strategi, Jakarta: PT RajaGrafindo Persada.

Dan, Nimmo, 2004. Komunikasi Politik: Komunikator, Pesan Dan Media. Bandung: Rosda karya

Daymon, Christine, Immy Holloway, 2008. Metode-metode riset kualitatif dalam public relations dan marketing communications. Terjemahan. Yogyakarta: Bentang

Effendy, Onong U. 1986. Dimensi-dimensi Komunikasi. Cetakan Kedua. Bandung: Alumni

Eriyanto, 2001, Analisis Wacana: Pengantar Analisi Teks Media, LKiS, Yogyakarta.

Hamad, Ibnu. 2004. Konstruksi Realitas Politik Dalam Media Massa. Jakarta: Granit

Ishwara, Luwi. 2005. Catatan-catatan Jurnalisme Dasar. Cetakan Pertama. Jakarta: Penerbit Buku Kompas.

Kriyantono, Rachmat, 2006.Riset Komunikasi, Jakarta: Kencana Prenada Group

Michael Rush \& Philip Althoff, 2005. Pengantar Sosiologi Politik, Jakarta: PT Raja Grafindo Persada,

M.Romli, Asep Syamsul. 2012. Jurnalistik Online: Panduan Praktis Mengelola Media Online (Dilengkapi Kiat Blogger, Teknik SEO, dan Tips Media Sosial) Bandung: Nuansa Cendekia.

Nugroho, Adi. Analisis Framing Pemberitaan Pilgub Jateng Pada Harian Suara Merdeka. Semarang: Jurnal Interaksi Vol 1 No 1 (2012)

Rakhmat, Jalaludin. 2007. Metode Penelitian Komnikasi. Bandung: PT Remaja Rosdakarya

Richard West, Lynn H. Turner, 2007. Pengantar teori Komunikasi Edisi 3. Jakarta: Salemba Humanika 


http://journal.umpo.ac.id/index.php/aristo / aristo@umpo.ac.id

Rivers, William, L. Jay W. Jensen, Theodore. Peterson. 2015. Media Massa dan Masyarakat Modern. Jakarta: Prenadamedia Group

ShoemakerPamela, J dan Stephen D. Reese. 1996. Mediating the message: Theories of influences On mass media content. USA: Longman

Sudibyo, Agus.2001. Politik Media Dan Pertarungan Wacana. Yogyakarta: lkis

Suprayogo Imam, Tobroni. 2001. Metodelogi Penelitian Sosial-Agama. Cetakan Pertama. Bandung: Rosda karya.

Tatik Yuniarti, Kartini Rosmala.2011. Analisis Framing Berita Makelar Kasus Di Institusi Kepolisian Pada Surat Kabar Kompas Dan Republika Edisi 19 - 23 Maret 2010 (Studi Analisis Framing Model Pan Dan Kosicki). Bekasi: Jurnal FKSB MAKNA Vol 2, No 01 (2011). 